\title{
Article
}

\section{The Combatant's Privilege in Asymmetric and Covert Conflicts}

\author{
Jens David Ohlin ${ }^{\dagger}$
}

INTRODUCTION.

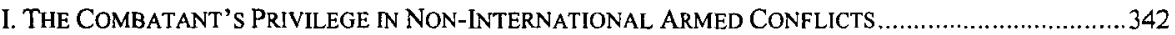

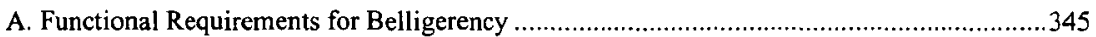

B. Belligerency Requirements for Regular Armed Forces ............................................... 348

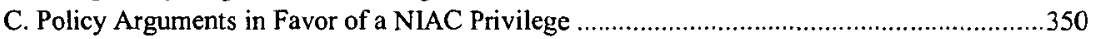

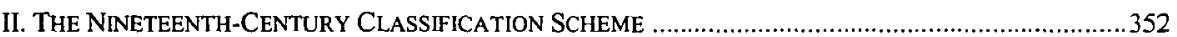

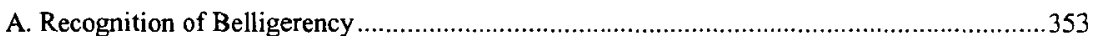

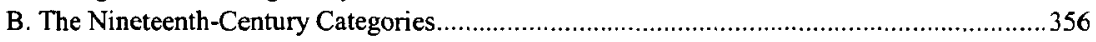

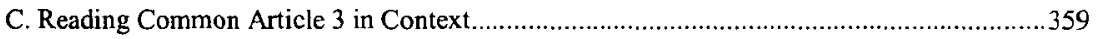

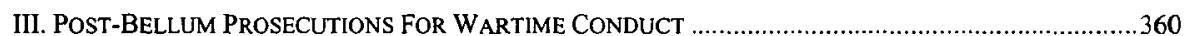

A. Prosecution for Loyalty-Based Offenses ................................................................... 361

IV. THE PRIVILEgE OF COMBATANCY IN MODERN ASYMMETRICAL CONFLICTS .................................368

A. The Privilege Applies in the Armed Conflict Against al-Qaeda ..........................................368

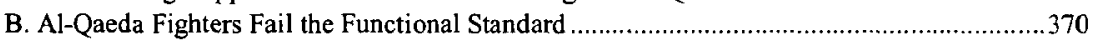

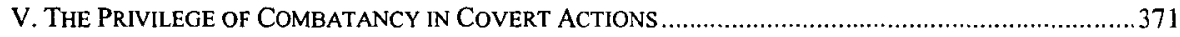

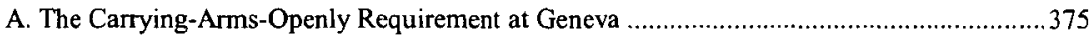

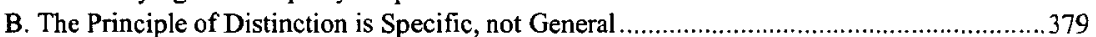

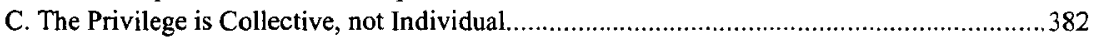

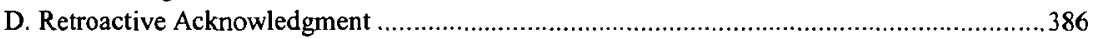

E. Mixed Deployment of Complex Weapons Platforms................................................ 387

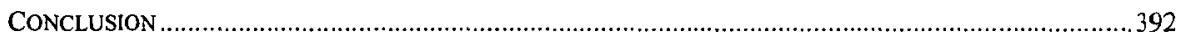

\section{INTRODUCTION}

As the United States has engaged in an unprecedented campaign of targeted killings against members of al-Qaeda and associated forces, various agencies within the government have engaged in increasingly pitched squabbling regarding their respective control over drone strikes in multiple foreign theaters. ${ }^{1}$ Authority and responsibility has vacillated between the Central Intel-

$\dagger \quad$ Professor of Law, Cornell Law School. I am grateful to Thomas Mills of the Comell Law School library for research assistance. The following individuals provided feedback and advice: William Banks, Robert Chesney, Mike Dorf, Charlie Dunlap, Matt Evangelista, Kevin Heller, Marty Lederman, Sarah Kreps, Steve Vladeck, John Witt, and participants in my Jurisprudence of War seminar.

1. For a description of the conflict, see Carlo Munoz, Turf Battle Builds Quietly in Congress over Control of Armed Drone Program, THE HILL (Apr. 9, 2013), http://thehill.com 
ligence Agency (CIA) and the Defense Department's Joint Special Operations Command (JSOC), the former being an intelligence agency tasked with both intelligence and covert operations directives, and the latter a military organization under the direction of the Secretary of Defense. ${ }^{2}$ In addition to the inherent policy questions in this turf battle, there are urgent elements of domestic and international law simmering beneath the surface. Some critics have suggested that CIA officers should not be involved in drone operations because CIA officers are non-uniformed individuals that do not meet the international law standards for privileged belligerency. ${ }^{3}$ According to this argument, the calculus regarding the appropriate agency for drone operations ought to take into account that international law does not confer the combatant's privilege on nonuniformed CIA employees. ${ }^{4}$

A competing school of thought disagrees with this analysis on the grounds that privileged belligerency - as a legal concept-is entirely a creature of international armed conflict (IAC) and therefore has no relevance in a noninternational armed conflict (NIAC). ${ }^{5}$ Since the parties to the armed conflict include a non-state actor, al-Qaeda, the armed conflict cannot be an IAC. ${ }^{6} \mathrm{Un}$ der this view, the appropriate legal categories are government forces and opposition fighters, not privileged and un-privileged belligerents.' I describe this as the orthodox position under International Humanitarian Law (IHL) because it is often asserted in classic texts that the privilege of belligerency does not apply in NLAC, and the drafters of the Geneva Conventions and Additional Protocol

/homenews/administration/292501-turf-battle-builds-quietly-over-control-of-armed-drone-program-.

2. See Fred Kaplan, The Drones Are in the Details: Why it Matters if the Pentagon Takes Command of the CIA's Drones, SLATE (Mar. 21, 2013), http://www.slate.com/articles/news _and_politics/war_stories $/ 2013 / 03 / j o h n \_b r e n n a n_{-}$wants_the_pentagon_to_take_command_of_the_cia_s _drone_strike.html.

3. Gary Solis, CIA Drone Attacks Produce America's Own Unlawful Combatants, WASH. POST, Mar. 12, 2010, http:/www.washingtonpost.com/wp-dyn/content/article/2010/03/11/AR201003 1103653.html.

4. The privilege of belligerency is the right of all lawful combatants to kill enemy soldiers without criminal liability. In this Article, the terms "privilege of belligerency" and "privilege of combatancy" are used interchangeably.

5. See Nils Melzer, Targeted Killing In InTERnational LaW 323 (2008) ("Current conventional IHL governing non-international armed conflict [(NIAC)] does not use the notion of "combatant,' nor does it provide for combatant privilege within the meaning of immunity from prosecution for lawful acts of war."); GARY D. SOLIS, THE LAW OF ARMED CONFLICT: INTERNATIONAL HUMANITARIAN LAW IN WAR 191 (2010) (noting that in NIAC there "may be combat in the literal sense, but in terms of LOAC there are fighters, rebels, insurgents, or guerrillas who engage in armed conflict, and there are government forces, and perhaps armed forces allied to the government forces"); Knut Dormann, Combatants, in THE OXFORD COMPANION TO INTERNATIONAL CRIMINAL JUSTICE 268, 269-70 (Antonio Cassese ed., 2009); Ryan Goodman, Good Reasons May Exist to Close ClA Drone Program-But Claim That CIA Agents Are "Unprivileged Belligerents" Is Not One of Them, JUST SECURITY (Sept. 25, 2013, 11:25 AM), http://justsecurity.org/1150/good-reasons-exist-close-cia-drone -program-but-claim-cia-agents-unprivileged-belligerents ("These particular privileges and immunities have no relevance to non-international armed conflict.").

6. See, e.g., Noam Lubell, The War (?) Against Al-Qaeda, in INTERNATIONAL LAW AND THE CLASSIFICATION OF CONFLICTS 421, 431 (Elizabeth Wilmshurst ed., 2012) ("The short answer to this proposition would be that international armed conflict must be between two (or more) States, and since Al-Qaeda is not a State, we do not have an international armed conflict.").

7. See, e.g., Michael A. Newton, Exceptional Engagement: Protocol I and a World United Against Terrorism, 45 TEX. INT'L L.J. 323, 343 (2009) (claiming that there is no category of combatant in NIACs); see also SoLIS, supra note 5, at 191. 


\section{II refused to codify one. ${ }^{8}$}

The orthodox position is mistaken and the original critics have it right: there is something wrong with CIA employees engaging in drone strikes. However, CIA critics have opposed the agency's participation for the wrong reasons. CIA employees lose the privilege of belligerency because their actions are covert and unacknowledged - a type of force never consistent with the privilege of belligerency. ${ }^{9}$ Strangely, the current literature on IHL has consistently avoided this issue, demonstrating a blind spot with regard to covert action. ${ }^{10}$ Simply put, covert action is incompatible with the privilege of belligerency because the privilege is a collective-not individual-privilege and can only be asserted if a collective fighting force first acknowledges the use of force and confirms that the appropriate individuals fight on its behalf. ${ }^{11}$ Without this necessary step, there is no privilege for the individual to assert.

Before proceeding with this argument, we must first address the threshold question of whether the privilege of combatancy applies to the armed conflict with al-Qaeda. There are already calls to recognize the privilege of belligerency in the context of transnational NIACs, based on the argument that transnational NIACs cross international boundaries and therefore, by analogy, ought to import the legal architecture of IACs, including the privilege of combatancy. ${ }^{12}$ This Article advances a stronger position: the privilege of belligerency might

8. See 1 INT'L COMM. ON RED CROSS, CUSTOMARY INTERNATIONAL HUMANITARIAN LAW: RULES 11, 384 (Jean-Marie Henckaerts \& Louise Doswald-Beck eds., 2005) [hereinafter ICRC, CUSTOMARY IHL RULES] (stating that "[c]ombatant status . . . exists only in international armed conflicts" and that "[s]tate practice establishes this rule as a norm of customary international law applicable in international armed conflicts"); Robert Chesney, Who May Be Killed? Anwar al-Awlaki as a Case Study in the International Legal Regulation of Lethal Force, 13 Y.B. INT'L HUMANITARIAN L. 3, 41 (2010) (asking whether concept of combatant can be disaggregated into combatant for purposes of privileged belligerent and combatant for the purpose of the principle of distinction); David Kretzmer, Targeted Killing of Suspected Terrorists: Extra-Judicial Executions or Legitimate Means of Defence?, 16 EURO. J. INT'L L. 171, 197-98 (2005) (concluding that the principle of distinction in NIACs requires combatants, though they remain unprivileged).

9. Covert action is defined in U.S. law as "an activity or activities of the United States Government to influence the political, economic, or military conditions abroad, where it is intended that the role of the United States Government will not be apparent or acknowledged publicly . . ." 50 U.S.C. $\S$ 3093 (2012).

10. The closest discussion is a section on spies in the famous article by Baxter. See RICHARD BAXTER, So-Called 'Unprivileged Belligerency': Spies, Guerrillas, and Saboteurs, in HUMANIZING THE LAWS OF WAR: SELECTED WRITINGS OF RICHARD BAXTER 37, 41-42 (Detlev F. Vagts et al. eds., 2013) (concluding that spies are unprivileged and prosecutable under domestic law); see also EMILY

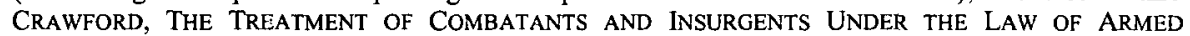
CONFLICT 53-54 (2010) (addressing the consequences of denial of combatant status).

11. For literature recognizing the collective nature of belligerent rights, see Nils Melzer, The Principle of Distinction Between Civilians and Combatants, in THE OXFORD HANDBOOK OF INTERNATIONAL LAW IN ARMED CONFLict 296, 303 (Andrew Clapham \& Paola Gaeta eds., 2014) (concluding that combatant privilege and POW status are tied to collective criteria and entitlements). Compare Christopher Kutz, The Difference Uniforms Make: Collective Violence in Criminal Law and War, 33 PHIL. \& PUB. AFF. 148, 173 (2005) (defending the collective approach), with JEFF MCMAHAN, KILLING IN WAR 81 (2009) (rejecting the collective approach in favor of individual analysis of moral rights in warfare).

12. See Geoffrey S. Corn, Thinking the Unthinkable: Has the Time Come To Offer Combatant Immunity to Non-State Actors?, 22 STAN. L. \& POL'Y REV. 253, 272 (2011) (proposing extension of privilege to non-state actors in transnational NLACs). Corn argues that transnational NIACs are de facto international conflicts and should be afforded the privilege of combatancy, just as national wars of liberations were treated as international conflicts though technically internal in nature. 
apply in more traditional NIACs, including civil wars, because the deep structure of the law of war permits armed fighting groups to engage in war against each other, regardless of whether the armed groups constitute states. The only reason to deny this claim is to fall victim to rank statism. Of course, it would be foolish to argue that this principle is embodied in customary international law since most states (or at least their official statements) reject the right of rebels to engage in combatancy against the state. This Article concludes that these statements are either mistaken or exaggerated and that if states understood the deep structure of the law of war, they might be less categorical in their statements. ${ }^{13}$ In particular, statements regarding the exclusion of the privilege in NIACs often rely on the Geneva Conventions. However, as will be demonstrated in Part I, Common Article 3 of the Geneva Conventions is often misread in this regard: In fact it neither explicitly codifies nor proscribes the combatant's privilege. Rather, it merely preserves the status quo, and so to understand the post-Geneva combatant's privilege one needs to understand the pre-Geneva privilege and look to nineteenth century practices. In keeping with this analysis, Part II examines U.S. Civil War practices and the writings of the nineteenthcentury publicists and finds strong precedent for applying the privilege in some NIACs. At the very least, the standard proposition that the privilege never applies in NIACs is an unsupported exaggeration.

The argument in this Article lingers in the netherworld between lex lata and lex ferenda, between the law as it currently stands and the law as it ought to be. The goal of the analysis is to identify the implicit structure of the law, even though it remains unacknowledged in positive international law as defined by a standard interpretation of international law sources. However, structure should never be ignored and here especially so. If the proper structure was recognized, it might become manifest in positive law and trigger a broader understanding of the privilege of belligerency.

The obvious objection is that states have always maintained-and continue to maintain - the right to prosecute rebels for taking up arms against the government. This would suggest that the privilege does not apply in NIACs. However, the literature has generally viewed such prosecutions without sufficient detail to their criminal content. As this Article will show, there is a marked difference between prosecuting a rebel for murder and prosecuting a rebel for treason or taking up arms against the government. Under the view advanced below, the privilege of combatancy negates the former but not the latter. Even with the privilege of combatancy in force in a NIAC, states may still prosecute rebels for loyalty-based offences stemming from their decision to rebel against the government; the privilege simply prevents the government from prosecuting them for murder. The privilege transforms what would otherwise be an illegal act of murder into a lawful act of belligerency, but it does not excuse the rebel from his or her constitutional or domestic obligation of loyalty to the government. While this distinction may appear razor thin, it is sufficiently

13. See SANDESH SIVAKumaran, THE LAW OF NON-INTERNATIONAL ARMEd CONFLICT 515 (2012) ("Although states may prove resistant to the idea, there is some practice suggesting that the principle of combatant immunity can be applied in certain non-international armed conflicts."). 
robust to carry the conceptual weight of the argument. States may recognize the privilege but also, in some situations, prosecute rebels.

In Part V, this Article then examines the particular mode of military engagement-covert action-most commonly used in the armed conflict with non-state terrorist groups. This requires interrogating a second orthodoxy of IHL: that unacknowledged use of force is consistent with the privilege of combatancy. Under the orthodox position, Defense Department forces, wearing traditional uniforms and military insignia, could be assigned to a covert action assignment authorized by the President under Title 50 of the U.S. Code. ${ }^{14}$ This was the structure of the Navy SEAL raid against Osama Bin Laden in Abbottabad, Pakistan, that was carried out by traditional military forces under the operational command of CIA Director Leon Panetta pursuant to Title $50 .{ }^{15}$ It was generally assumed that the privilege of belligerency survived this migration from Title 10 (Department of Defense authority) to Title 50 (covert action). ${ }^{16}$ This view is mistaken, as long as the use of force remains unacknowledged. ${ }^{17}$ The reasons for this conclusion are two-fold. First, the privilege requires that the individual belong to a fighting force that carries its arms openly and wears a distinctive emblem recognizable at a distance. ${ }^{18}$ Carrying arms openly is impossible when the use of force is unacknowledged. Second, the distinctive emblem cannot be a generic military uniform; it must unambiguously identify the soldier as a member of a particular fighting force. This conclusion is supported by the underlying objective of the insignia requirement, which is not simply to distinguish civilians and soldiers in the generic sense but also to distinguish enemy soldiers from friendly soldiers and neutral third parties.

Often the military force-say the deployment of a drone-might be a coordinated effort with a mix of CIA and uniformed Defense Department actors working together. ${ }^{19}$ This too represents an under-theorized problem. Section V.E will therefore address how the concept of carrying arms openly applies to complex weapons platforms with multiple individuals engaged cooperatively in their deployment. The concept of carrying arms openly applies in a simple way when the weapon is a rifle. But when a team of combatants in multiple locations co-deploys the armament, the question becomes how to evaluate the mixed nature of the team with uniformed and non-uniformed per-

14. See 50 U.S.C. $\$ 3093$ (2012).

15. For a helpful analysis, see generally Robert Chesney, Military-Intelligence Convergence and the Law of the Title 10/Title 50 Debate, 5 J. NAT'L SEC. L. \& POL'Y 539, 539 (2012) (arguing that the Bin Laden raid exemplifies an increasing convergence of military and intelligence activities); Andru E. Wall, Demystifying the Title10-Title 50 Debate: Distinguishing Military Operations, Intelligence Acivities \& Covert Action, 3 HARV. NAT'L SECURITY J. 85, 85-86 (2011) (same).

16. Title 10 gives the Secretary of Defense control and authority over the armed forces. See 10 U.S.C. $\$ 113(\mathrm{~b})(2012)$.

17. There is a factual argument that the U.S. government subsequently acknowledged the use of force in President Barack Obama's presidential address, which might arguably have rescued the privilege of combatancy retrospectively. See Peter Baker et al., Bin Laden Is Dead, Obama Says, N.Y. TIMES, May 1, 2011, http://www.nytimes.com/2011/05/02/world/asia/osama-bin-laden-is-killed.html.

18. Some scholars argue that these requirements do not apply to regular armed forces, a view that is rejected in Section I.B.

19. See Chesney, supra note 15 , at 562 (noting the presence of a shadow war with CIA assets working alongside military assets in the armed conflict against al-Qaeda). 
sonnel. The best reading of the underlying principle of openness in warfare entails that a mix of overt and covert operatives in the deployment of a complex weapons system is not "open" and therefore will negate the combatant's privilege.

Both the argument regarding the privilege of belligerency in NIACs and the argument regarding covert action are unorthodox according to the received wisdom of the field. The arguments will appeal to first principles to show that the orthodox position is mistaken and requires revision. However, this should not be described as a mere de lege ferenda proposal, sounding in policy or normative arguments or moral philosophy. Rather, it is a proposal sounding in the structure of the law itself, a structure that already exists and only needs to be rendered explicit.

\section{THE COMBATANT'S PRIVILEge IN NON-INTERNATIONAL ARMEd CONFLICTS}

The following Part argues that the current literature often uncritically assumes that the privilege of combatancy does not apply to non-international armed conflicts. The standard view is that the very legal concept of "combatant" is a creature of international armed conflicts and the international laws of war that regulate them. ${ }^{20}$ Under this view, non-international armed conflicts have no combatants at all—only government troops and rebels. ${ }^{21}$ Government forces are authorized to commit killings by their own domestic law, while rebels are not. ${ }^{22}$ Consequently, government troops will not be prosecuted at the conclusion of a civil war while vanquished rebels could be prosecuted for their belligerent acts against the government. ${ }^{23}$

It is important to remember that the privilege of combatancy is both a prohibition and a license that can be inferred from the prohibition. First, the privilege is a prohibition against nation-states that might be tempted to prosecute enemy soldiers for killing in wartime. The privilege of combatancy operates as a rule of international law forbidding states from engaging in such prosecutions. ${ }^{24}$ A state may only prosecute enemy soldiers for violating the laws of war by, say, deliberately killing civilians or engaging in other illegal acts of perfidy. But a state would be violating international law if it were to go ahead and prosecute the enemy for garden-variety acts of combat during the war. In-

20. See Newton, supra note 7 , at $342-43$.

21. See Geoffrey S. CORN et AL., THE LAW of ARMEd CONFlict: AN Operational APPROACH 134 (2012) ("Historically, only the representatives of sovereign governments were privileged belligerents, as they were asked to represent their government and charged with the responsibility of using lawful force on behalf of their nation to subdue the enemy; unprivileged belligerents do not represent lawful (competent) state authority.").

22. See Melzer, supra note 11, at 318 (noting that "domestic legislation in most countries provides members of state armed forces with protection from prosecution for lawful acts of state (ie a status equivalent to combatant privilege)"). Solis argues that during the Spanish Civil War there was a "special agreement" that both sides of the conflict would grant prisoners a "status equivalent to POW," though it was not technically POW status. See SoLIS, supra note 5, at 191.

23. A full analysis of this issue is provided infra Section III.A.

24. For a discussion of the privilege, see Waldemar Solf, The Status of Combatants in NonInternational Armed Conflicts Under Domestic Law and Transnational Practice, 33 AM. UNIV. L. REV. $53,57-58(1983)$. 
stead, the current scheme assumes that such soldiers ought to be granted POW status and returned at the conclusion of hostilities. ${ }^{25}$ From this general scheme, one can infer a license that runs to each individual soldier. ${ }^{26}$ Each soldier enjoys the privilege of combatancy and can engage in wartime killing against legitimate targets without fear of criminal prosecution. The privilege applies because the killing of an enemy soldier during war is no crime at all. ${ }^{27}$

Most scholars assume that this scheme does not apply in civil wars. ${ }^{28} \mathrm{~A}$ state may prosecute its enemies after a civil war, precisely because those enemies are subjects who rose up to defy the government. There is a certain logic in this rule, because if a subject were to commit a single killing of a government official during peacetime, that would be considered murder and subject to criminal prosecution. It would seem odd to suggest that a group of bandits and outlaws could bootstrap themselves into immunity from prosecution simply by killing more victims - an absurd result. More importantly, the standard view is that the drafters of the Geneva Conventions in 1949 refused to apply the new legal regulations of the Geneva Conventions to civil wars precisely because they wanted to retain the authority to prosecute, as outlaws and bandits, internal enemies that rose up against the state. ${ }^{29}$ The one exception was Common Article 3 , which provided limited protections to enemy soldiers during civil wars, including the right to humane treatment, which meant that captured enemies could not be summarily executed or tortured. But the gist of the Geneva negotiations in 1949 was that states wanted to shield most of their conduct in internal civil wars from international legal regulation; they wanted to retain the right to prosecute rebels as criminals. ${ }^{30}$ That explains the standard view that the privilege of combatancy does not apply in non-international armed conflicts. ${ }^{31}$

Although it is true that there exists no codified privilege of combatancy in

25. Geneva Convention Relevant to the Treatment of Prisoners of War arts. 82-89, Aug. 12, 1949, 6 U.S.T. 3316, 75 U.N.T.S. 135 [hereinafter Third Geneva Convention].

26. See CRAWFORD, supra note 10, at 53 n.11; Derek Jinks, Protective Parity and the Laws of War, 79 NOTRE DAME L. REV. 1493, 1502 (2004).

27. See Instructions for the Government of Armies of the United States in the Field, General Order No. 100, art. 57 (Apr. 24, 1863) [hereinafter Lieber Code] ("So soon as a man is armed by a sovereign government and takes the soldier's oath of fidelity, he is a belligerent; his killing, wounding, or other warlike acts are not individual crimes or offenses. No belligerent has a right to declare that enemies of a certain class, color, or condition, when properly organized as soldiers, will not be treated by him as public enemies."). For a discussion of the privilege, see YORAM DINSTEIN, THE CONDUCT OF HoSTILITIES UNDER THE LAW OF INTERNATIONAL ARMED CONFlict 33 (2d ed. 2010); Sean Watts, Present and Future Conceptions of the Status of Government Forces in Non-International Armed Conflict, 88 INT'L L. STUD. 145, 151-52 (2012) (noting disagreement over whether the combatant's privilege is an immunity from prosecution or an affirmative license).

28. See, e.g., Nils Melzer, Bolstering the Protection of Civilians in Armed Conflict, in REALIZING Utopia: THE FUTURE OF INTERNATIONAL LAW 508, 516 (Antonio Cassese ed., 2012) (concluding that international law is unlikely to extend the privilege to non-international conflicts).

29. See, e.g., Louise Doswald-Beck, Private Military Companies Under International Humanitarian Law, in FROM MERCENARIES TO MARKET: THE RISE AND REGULATION OF PRIVATE MILITARY COMPANIES 115, 116-17 (Simon Chesterman \& Chia Lehnardt eds., 2007) (concluding that the drafters of the 1949 Geneva Conventions refused to confer POW status on rebels).

30. See Watts, supra note 27 , at 153 (noting state reluctance to extend combatant privilege to civil wars and concluding that "general reluctance to yield sovereignty over internal affairs and lack of consensus have all contributed to the NIAC legal void").

31. See Anthony Cullen, The Concept of Non-International ARMEd Conflict IN INTERNATIONAL HUMANITARIAN LAW 58 (2010). 
non-international armed conflicts, the situation is far more nuanced and complex than the current literature assumes. ${ }^{32}$ The privilege of combatancy may not apply in most non-international armed conflicts, but there are situations where functional arguments have greater purchase than commonly understood. First, the armed conflict against al-Qaeda is not a civil war in the traditional sense, though it is an armed conflict "not of an international character" since it only involves one formal state. ${ }^{33}$ Given that the drafters of the Geneva Conventions did not explicitly contemplate an armed conflict of this type, it is unclear whether the conflict should be governed by the legal rules associated with international conflicts or the rules for civil wars. The argument in favor of applying the rules from international armed conflicts is simple: the conflict with alQaeda is transnational and crosses international boundaries, thus implicating many of the operational and regulatory concerns of IHL. ${ }^{34}$ The argument for applying the rules of NIAC is that the armed conflict is between a state and non-state actor, just like a civil war. Applying these arguments to the combatant's privilege, there might be reason to think that the privilege applies to transnational armed conflicts like the one against al-Qaeda, since it is unclear whether the armed conflict is properly classified as an IAC, NIAC, or somewhere in between. ${ }^{35}$

Second, the situation is equally complex when rebels control a significant amount of territory and start fulfilling the regulatory powers that one normally associates with governmental action. In that situation, the rebel forces become a de facto state-like entity that may even be recognized as a newly formed state by some third-party observers. Insofar as the rebels are in control of territory and population, they may even exhibit de facto sovereignty. ${ }^{36}$ In these situations it becomes excessively formalistic to deny the combatant's privilege to

32. There are some notable exceptions. See, e.g., SIVAKUMARAN, supra note 13, at 515-20; Ian Henderson, Civilian Intelligence Agencies and the Use of Armed Drones, 13 Y.B. INT'L HUMANITARIAN L. 133, 147 (2010) (concluding that government forces but not insurgents enjoy the combatant's privilege in NIACs).

33. The U.S. Supreme Court concluded that the armed conflict was not of an international character and therefore Common Article 3 applied to government conduct. See Hamdan v. Rumsfeld, 548 U.S. 557, 630 (2006) (noting the policy argument that the scope of Common Article 3 should be as wide as possible); see also Fionnuala D. Ni Aolàin, Hamdan and Common Article 3: Did the Supreme Court Get it Right?, 91 MINN. L. REv. 1523, 1524 (2007) (decrying the "clumsiness of application and a dearth of analytical rigor" in the Supreme Court's analysis of Common Article 3); Lubell, supra note 6, at 429 (noting the government's acceptance of the Supreme Court's classification).

34. But see Marko Milanovic \& Vidan Hadzi-Vidanovic, A Taxonomy of Armed Conflict, in RESEARCH HANDBOOK ON INTERNATIONAL CONFLICT AND SECURITY LAW 256, 307 (Nigel D. White \& Christian Henderson eds., 2013) (discussing the shift in the U.S.'s understanding of the conflict from IAC to NIAC),

35. The lack of certainty in applying the classification system is well known. See Nì Aolàin, supra note 33, at 1553-55; Tom Farer, Humanitarian Law \& Armed Conflicts: Toward the Definition of "International Armed Conflict," 71 CoLUM. L. REv. 37, 43 (1971) ("One of the most assured things that might be said about the words 'armed conflict not of an international character' is that no one can say with assurance precisely what meaning they were intended to convey.").

36. For a discussion of de facto sovereignty, see Boumediene v. Bush, 553 U.S. 723, 754 (2008) (holding that the writ of habeas corpus runs to Guantanamo Bay because the United States enjoys de facto sovereignty over the military base in Cuba). See also Anthony J. Colangelo, 'De facto Sovereignty": Boumediene and Beyond, 77 GEO. WASH. L. REV. 623, 625 (2009) (noting that the Supreme Court specifically rejected de jure sovereignty in favor of de facto sovereignty as the relevant standard for the writ). 
these soldiers. ${ }^{37}$ Indeed, under the orthodox view, the existence or nonexistence of the privilege would depend entirely on the prior question of whether the rebel territory constitutes a new state. If it is recognized as a new state, the soldiers are privileged; if the rebel territory is not a state, the soldiers are liable. This analysis is highly formalistic and ties the fate of individual soldiers to a macro-determination of public international law that remains utterly obscure to them. This suggests that the privilege of combatancy may have a role to play in some marginal NIAC situations where the basic prerequisites of the conflict look more like an IAC than a NIAC.

The following argument proceeds in three steps. First, Section I.A considers the functional requirements for lawful belligerency and notes that state authority is not logically required for them. At a conceptual level, non-state actors are capable of meeting the functional requirements for collective belligerency; recognizing the privilege associated with that belligerency would simply acknowledge the fact that the non-state actor meets these functional requirements. Second, Section I.B asks whether regular armed forces of a state party to a conflict are required to meet the functional standards of belligerency in order to gain the privilege of combatancy. The standard answer is no, based in part on the wording of the Hague Convention of 1909 and the Geneva Conventions of 1949. This Article disputes that common assumption because it produces incoherent results. The more plausible answer is that regular armed forces are also required to meet the functional requirements of belligerency because those requirements are constitutive of a definition of being a regular armed force in the first place. Third, Section I.C canvasses the policy reasons-which are substantial-for extending the privilege to some NIAC situations.

\section{A. Functional Requirements for Belligerency}

The most obvious argument in favor of a limited recognition of the privilege in at least some non-international armed conflicts is the nature of the standards for the privilege, which are general and do not require the existence of a state party to be fulfilled. Only a formalist reading of the requirements for privileged belligerency supports the conclusion that combatants in civil wars can never be legitimate belligerents. An analysis of the particular requirements follows.

The requirements for privileged belligerency have remained remarkably stable over time. The well-known requirements for prisoner of war status and, by extension, the privilege of combatancy are outlined in Article 4 of the Gene-

37. A few scholars have produced arguments that, when taken to their logical extreme, imply that failure to grant the privilege in NIAC risks collapsing $j u s$ in bello with jus ad bellum, because the question of legitimacy of war aims is, properly speaking, the exclusive domain of jus ad bellum. The neutrality of jus in bello is only preserved by complete agnosticism regarding the legality of the use of force, even by a non-state belligerent in a civil war. See, e.g., Jasmine Moussa, Can Jus ad Bellum Override Jus in Bello? Reaffirming the Separation of the Two Bodies of Law, 90 INT'L REV. RED CROSS 963 (2008); see also François Bugnion, Jus ad Bellum, Jus in Bello and Non-International Armed Conflicts, 6 Y.B. INT'L HUMANITARIAN L. 167 (2003) (arguing that some rudimentary principles of jus ad bellum apply in non-international conflicts through the doctrine of the recognition of belligerency). 
va Conventions, ${ }^{38}$ though they were already listed in substantially the same form in the Hague Regulations of $1899^{39}$ and the Hague Regulations of $1907{ }^{40}$ The requirements include: (a) a command structure with soldiers "commanded by a person responsible for his subordinates," (b) the wearing of a "fixed distinctive sign recognizable at a distance," (c) carrying arms openly, and (d) conducting operations "in accordance with the laws and customs of war." As should be immediately clear, these requirements are independent of the existence of a formal state entity standing behind the military force: non-state actors are capable of marshaling an organized armed force with a hierarchical command structure with soldiers who wear a fixed sign, carry their arms openly, and conduct hostilities in accordance with the laws of war. ${ }^{42}$ These requirements are all independent of formal political legitimacy.

Negotiators at Geneva in 1947 were well aware of the broad sweep of these functional criteria and there was a major push to allow militias and other non-state actors the benefits of POW status and its implied privilege of combatancy, especially in cases where the militia controlled territory of its own. ${ }^{43}$ This proposal was not accepted and did not make its way into the final Convention text. ${ }^{44}$ The delegates adopted a compromise solution that extended POW status to militias and other resistance movements in occupied territories as long as they were connected to a state party to the conflict. ${ }^{45}$ In other words, militias involved in pure civil wars were not covered by Article 4's POW protections. Militias were only covered if they were operating in occupied territory on behalf of another state engaged in an international armed conflict with the occupying power. ${ }^{46}$ All other militias and non-state actors are covered by Common

38. Third Geneva Convention, supra note 25, art. 4.

39. Convention with Respect to the Laws and Customs of War on Land, July 29, 1899, Annex, Regulations Respecting the Laws and Customs of War on Land, 32 Stat. 1803, 1811 [hereinafter Hague Convention of 1899].

40. Convention Respecting the Laws and Customs of War on Land, Oct. 18, 1907, Annex, Regulations Respecting the Laws and Customs of War on Land, 36 Stat. 2277, 2295-96.

41. Third Geneva Convention, supra note 25 , art. 4.

42. The Lieber Code refers to organization by a "sovereign government" but not a sovereign state. See Lieber Code, supra note 27 , art. 57 ("So soon as a man is armed by a sovereign govermment and takes the soldier's oath of fidelity, he is a belligerent; his killing, wounding, or other warlike acts are not individual crimes or offenses. No belligerent has a right to declare that enemies of a certain class, color, or condition, when properly organized as soldiers, will not be treated by him as public enemies.").

43. INT'L COMM. OF THE RED CROSS, COMMENTARY TO GENEVA CONVENTION (III) Relative to the TREATMENT OF PRISONERS OF WAR 30 (Jean Pictet ed., 1960) [hereinafter ICRC, COMMENTARY TO THIRD GENEVA CONVENTION] (noting the desire of the Red Cross to extend all protections from IACs to internal conflicts).

44. The proposal included the following text: "In all cases of armed conflict which are not of an international character, especially cases of civil war, colonial conflicts, or wars of religion, which may occur in the territory of one or more of the High Contracting Parties, the implementing of the principles of the present Convention shall be obligatory on each of the adversaries. The application of the Convention in these circumstances shall in no wise depend on the legal status of the Parties to the conflict and shall have no effect on that status." Id. at 31 . The events surrounding the failure to accept this proposal are analyzed in Richard R. Baxter, Ius in Bello Interno: The Present and Future Law, in LAW AND CIVIL WAR IN THE MODERN WORLd 518, 519-20 (John Norton Moore ed., 1974) ("The broad sweep of this stipulation proved to be too much for the majority of the states represented at the Diplomatic Conference."); Corn, supra note 12, at 263-64.

45. See ICRC, COMMENTARY TO THIRD GENEVA CONVENTION, supra note 43, at 49-50.

46. Id. at 54 . 
Article 3 and its more basic protections regarding humane treatment, which fall short of full POW status under Article $4 .^{47}$

The standard interpretation of this result is that a state could well prosecute rebels after winning a civil war. ${ }^{48}$ Common Article 3 would require the state to provide humane treatment to the captured rebels (meaning they could neither execute nor torture them), but they would not be required to recognize them as immune from criminal prosecution for their acts of belligerency. The standard argument for this interpretation is that the last clause of Common Article 3 states that the "application of the preceding provisions shall not affect the legal status of the Parties to the conflict," tary refers to as "essential" because "[w]ithout it Article 3 would probably never have been adopted." of Common Article 3 protection to armed conflicts "not of an international character" could be read to include immunity from post-conflict criminal prosecutions. ${ }^{51}$ However, negotiators were keen to avoid this interpretation:

It meets the fear that the application of the Convention, even to a very limited extent, in cases of civil war may interfere with the de jure Government's suppression of the revolt by conferring belligerent status, and consequently increased authority and power, upon the adverse Party. The provision was first suggested at the Conference of Government Experts in 1947 and was reintroduced in much the same words in all the succeeding drafts Conventions. It makes it absolutely clear that the object of the clause is a purely humanitarian one, that it is in no way concerned with the internal affairs of States, and that it merely ensures respect for the few essential rules of humanity which all civilized nations consider as valid everywhere and in all circumstances.

Consequently, the fact of applying Article 3 does not in itself constitute any recognition by the de jure Government that the adverse party has authority of any kind; it does not limit in any way the Government's right to suppress a rebellion by all the means-including arms-provided by its own laws; nor does it in any way affect that Government's right to prosecute, try and sentence its adversaries, according to its own laws.

This conclusion is an exaggeration. While it is clear that the delegates at Geneva rejected far more sweeping protections for non-state militias fighting in non-international armed conflicts, nothing in Common Article 3 explicitly rejects it. What Common Article 3 does include is a provision (paragraph 4) that otherwise preserves the status quo, so that Common Article 3 cannot be read as doing more than providing the protections that it explicitly codifies. But that just leaves open the question of the exact nature of the status quo at the time, a point that the existing commentaries often paper over. Whatever the existing framework was for the privilege of combatancy at the time the Geneva Conven-

47. Id. at 57

48. Id. at 40 ("As can be seen, Article 3 does not protect an insurgent who falls into the hands of the opposing side from prosecution in accordance with the law, even if he has committed no crime except that of carrying arms and fighting loyally."); Corn, supra note 12, at 268.

49. Third Geneva Convention, supra note 25, art. 3(4).

50. See ICRC, COMMENTARY TO THIRD GENEVA CONVENTION, supra note 43, at 43.

51. Id.

52. Id. 
tions were adopted, the adoption of Common Article 3 did not change it. That says nothing about the preexisting state of the law on the matter. As Part II will explain, that law was (and is) far more nuanced than it appears at first glance.

\section{B. Belligerency Requirements for Regular Armed Forces}

The functional requirements for belligerency ought to apply symmetrically for all parties to an armed conflict, regardless of their status. But most commentators disagree. Not only do these scholars deny that non-state actors can qualify for the privilege, but they also exempt regular state armies from having to fulfill the traditional requirements of belligerency in order to qualify for the privilege. In other words, regular state armies are entitled to the privilege by fiat, regardless of whether they meet the four functional requirements of belligerency. ${ }^{53}$ This view is mistaken and destroys the symmetry and reciprocity upon which the modern law of war is built.

The four requirements for lawful belligerency are listed in the Geneva Convention in connection with militias and "members of other volunteer corps," but the same requirements are not repeated for "members of the armed forces of a Party to the conflict." 54 This has prompted most scholars to conclude that members of the armed forces are exempt from the four criteria and that only militias are required to follow them in order to gain POW status and, by extension, the right of lawful belligerency. ${ }^{55}$ This view generates absurd results because it entails that regular armed forces are wholly exempt from the principled requirements of lawful belligerency. ${ }^{56}$

Consider the following hypothetical situation. The State of Hypothetica passes a statute creating a Department of Defense with a "regular" army. However, the army is not required to have a command structure, nor does it in fact operate with one. The members of the army wear no uniforms or fixed emblem identifying themselves as combatants. Furthermore, the soldiers of Hypothetica's "army" do not carry their arms openly, nor do they generally comply with the laws and customs of warfare. As a matter of course they deliberately target enemy civilians, commit acts of perfidy, and regularly declare that no quarter will be given. It would be absurd to conclude that Hypothetica's army is entitled to the combatant's privilege just because they are the de jure armed forces of a state party to an armed conflict. Indeed, one cannot conclude that Hypothetica is an "army" at all unless one has criteria for determining what counts as

\section{See infra note 55 .}

54. Third Geneva Convention, supra note 25, art. 4(1)-(2).

55. See, e.g., Melzer, supra note 11, at 303 (stating, "although visibility and respect for IHL are legal obligations which may be relevant for individual and collective entitlement to $\mathrm{POW}$-status or combatant privilege, they are not defining elements of armed forces within the meaning of IHL'); Jordan Paust, War and Enemy Status After 9/II: Attacks on the Laws of War, 28 YALE J. INT'L L. 325, 329 (2003).

56. For a discussion of this argument, see EA/412/71 Military Prosecutor v. Swarka [1974] (Isr.), reprinted in 7 ISRAEL Y.B. ON HUM. RTS. 264 (Yoram Dinstein ed., 1977). See also ICRC, CUSTOMARY IHL RULES, supra note 8, at 385-86 (discussing Rule 106, which requires that "[c]ombatants must distinguish themselves from the civilian population while they are engaged in an attack or in a military operation preparatory to an attack" and "[i]f they fail to do so, they do not have the right to prisoner-of-war status"). 
an army. The fact that a state labels a fighting group as an army is hardly dispositive of the matter. In fact, the correct criteria for defining an army are the functional criteria listed in Article 4(2) pertaining to militias. The whole point of enumerating the criteria for militia is that they ought to meet the basic parameters that fit our common-sense definition of what counts as an army, even if they are not defined as an army under domestic law.

The best reading of Article 4 is that the four requirements in Article 4(2) are already implicit in the definition of what counts as regular armed forces, and the inclusion of militias and volunteer corps was designed to include within the rule military units that operate in the same manner as regular armed forces. ${ }^{57}$ Dinstein's description of the framework is helpful: there is a presumption that regular armed forces already meet the requirements for belligerency, but that presumption is rebuttable if the force fails to meet one of the functional criteria. ${ }^{58}$ Soldiers who fail to meet the criteria, even if they belong to the regular armed forces, are ineligible for the privilege and can be prosecuted for their acts of belligerency. ${ }^{59}$ The fact that most fighting forces meet the requirements is uncontroversial. Indeed, an International Committee of the Red Cross (ICRC) study on customary law notes that military manuals require that their forces wear uniforms and carry their arms openly. ${ }^{60}$ Furthermore, the fixed insignia requirement is designed as a functional analogue to the fact that members of regular armed forces already wear uniforms and identifying insignia. ${ }^{61}$ Additional Protocol 1 of the Geneva Convention confirms this analysis, since the requirements of distinction and of carrying arms openly applies explicitly to all combatants, not just militias and volunteer forces. ${ }^{62}$

The combatant's privilege applies to government forces operating in both international and non-international conflicts, and they are not exempt from meeting the functional requirements of belligerency. This is an important in-

57. See DINSTEIN, supra note 27, at 42 \& n.231, for an analysis of Bin Haji Mohamed Ali v. Public Prosecutor, [1969] 1 A.C. 430 (P.C.) 449-50 (appeal taken from Malay.) (U.K.) (concluding that regular armed forces are required to meet the standards of belligerency); $c f$. Memorandum from Jay $\mathrm{S}$. Bybee, Assistant Attorney Gen., to Alberto R. Gonzales, Counsel to the President, and William J. Haynes II, Gen. Counsel of the Dep't of Def. 31 (Jan. 22, 2002) (suggesting that Taliban forces might not be eligible for POW status if they do not meet the functional requirements of Article 4). It should be noted that the Bybee memorandum includes several controversial and discredited arguments regarding the President's ability to ignore treaty-based and customary international law and the status of Afghanistan as a failed state. See, e.g., Jens David Ohlin, The Torture Lawyers, 51 HARV. INT'L L.J. 193, 199207 (2010).

58. See DINSTEIN, supra note 27 , at $42-43$.

59. See, e.g., Ex parte Quirin, 317 U.S. 1, 31 (1942) (finding that "unlawful combatants are likewise subject to capture and detention, but in addition they are subject to trial and punishment by military tribunals for acts which render their belligerency unlawful"); $c f$. BAXTER, supra note 10, at 44-45.

60. ICRC, CUSTOMARY IHL RULES, supra note 8, at 386 .

61. But see Paust, supra note 55, at 334 .

62. Protocol Additional to the Geneva Conventions of 12 August 1949, and Relating to the Protection of Victims of International Armed Conflicts art. 44, June 8, 1977, 1125 U.N.T.S. 3 [hereinafter Additional Protocol I] (requiring that a combatant carry arms openly "[d]uring such time as he is visible to the adversary while he is engaged in a military deployment preceding the launching of an attack in which he is to participate"). Article 44 also preserves "the generally accepted practice of States with respect to the wearing of the uniform by combatants assigned to the regular, uniformed armed units of a Party to the conflict." Id. No correlate provisions exist in Additional Protocol II goveming noninternational conflicts. 
sight because it means that U.S. and coalition military actions against al-Qaeda and associated forces can be scrutinized to determine whether government forces are operating consistently with the functional requirements and are therefore entitled to the associated privilege. As will become clear in Part V, there may be reasons to doubt that the requirements are met in cases involving CIA operatives or even covert actions involving uniformed military personnel. ${ }^{63}$

\section{Policy Arguments in Favor of a NIAC Privilege}

It should come as no surprise that some legal actors are in favor of applying the privilege in non-international conflicts, since there are multiple policy arguments to support an extension. First, extending the privilege to non-state actors will give them an incentive to comply with the laws and customs of war. ${ }^{64}$ If rebels are always unprivileged, then they will be subject to criminal prosecution after the war, up to and including capital punishment. What incentive do rebels have to comply with the laws of war if they know they will already be subject to criminal punishment-including execution-if they are defeated on the battlefield? ${ }^{65}$ Indeed, the privilege's absence from the civil war context gives the rebel extra incentive to fight desperately, up to and including violating customary norms of decency, in order to win the war and topple the government. Rebels know that victory is the only way to avoid criminal punishment and execution. On the other hand, the application of the privilege in a civil war gives rebels reason to comply with the laws of war in exchange for the privileges of professional belligerency and immunity from criminal prosecution. ${ }^{66}$

Indeed, civil wars often produce non-state actors that meet all of the attributes of sovereignty save actual de jure legitimacy. If a non-state actor is engaged in belligerency, controls territory, and engages in the functions typically associated with government, then the functional criteria for privileged belligerency ought to apply with equal force to the belligerent in a civil war. In a sense, the rebels become a proto-state entity and ought to be treated like one for purposes of the privilege.

Also, denying the privilege of belligerency in non-international armed conflicts is in stark tension with the recent jurisprudence from international tribunals regarding the distinction between international and non-international

63. See infra Part V.

64. See Com, supra note 12 , at 280.

65. See id. at 287 ("Because non-state belligerents are excluded from even the opportunity to qualify for such immunity (because they are not engaged in international armed conflict), they have absolutely no incentive to modify their conduct or tactics."); Melzer, supra note 11, at 318 (referring to the "destructive downward spiral" when insurgents become increasingly alienated from IHL norms); Moussa, supra note 37, at 988-89; Marco Sassoli, Taking Armed Groups Seriously: Ways To Improve Their Compliance with International Humanitarian Law, 1 J. INT'L HUMAN LEG. STUD. 5, 26-27 (2010) (discussing incentives); Sandesh Sivakumaran, Re-envisaging the International Law of Internal Armed Conflict, 22 EURO. J. INT'L L. 219, 245 (2011) (discussing immunity as an incentive for IHL compliance).

66. See SIVAKUMARAN, supra note 13, at 518 ("Recognizing that some sort of combatant immunity provides an incentive for members of the armed group to comply with the law, but also appreciating that states may or may not be willing to provide combatant immunity in the abstract and in advance of a conflict, alternative ways ahead need to be canvassed."). 
armed conflicts. ${ }^{67}$ For purposes of defining and punishing violators of war crimes, international courts have increasingly questioned the categorical distinction between international and non-international armed conflicts and have suggested that the prohibitions applicable in the former are now applicable by custom in the latter as well. ${ }^{68}$ This has produced a growing assumption that the classification of a conflict as international or non-international is less relevant for the purposes of applying criminal sanctions for serious violations of the law of war. ${ }^{69}$ While this does not directly entail the extension of the privilege of belligerency to civil wars, it does throw into stark relief the growing incoherence of treating international and non-international armed conflicts as categorically different for purposes of the combatant's privilege. If the classification scheme is largely irrelevant for purposes of understanding the nature and scope of the prohibitions embodied in the law of war, then perhaps this should give us pause before assuming that the distinction between IAC and NLAC is suddenly crucial for understanding the privilege. Perhaps there is growing pressure here as well.

Finally, one ought to reflect on the entire scheme represented by the orthodox interpretation of Common Article 3 and the POW standard expression in Article 4. If the orthodox position is correct, the drafters of Geneva left the world with a legal framework with two different types of armed conflict: international with privileged combatants fighting on both sides, and noninternational with government forces fighting rebels. ${ }^{70}$ This interpretation is repeated like a mantra in the literature. ${ }^{71}$ Perhaps it represents the will of the drafters at Geneva, but no one stops to ask whether it is logically coherent. The framework assumes that one can talk of an armed conflict without importing the language of belligerency. ${ }^{72}$ Since the drafters at Geneva wanted to import international oversight and regulation of civil wars, they crafted a provision (Common Article 3) that imposed substantial legal restraints during these conflicts, but they also wanted to exclude the moral equality of combatants from that framework. ${ }^{73}$ At bottom there is a deep tension in this move: for purposes of war crimes the drafters wanted to say that the conduct of hostilities during a civil war is not a matter of domestic sovereignty but is instead a matter of in-

67. See, e.g., CRAWFORD, supra note 10, at 6, 154; John Cerone, Jurisdiction and Power: The Intersection of Human Rights Law \& the Law of Non-International Armed Conflict in an Extraterritorial Context, 40 ISR. L. REV. 396, 396-412 (2007) (discussing convergence); Yoram Dinstein, Concluding Remarks on Non-International Armed Conflicts, 88 INT'L L. STUD. 399, 406 (discussing the "trend of" jus in bello governing international and non-international conflicts). But see Milanovic \& HadziVidanovic, supra note 34 , at 272 (suggesting that despite the "successes of the IAC/NIAC unification project in the past two decades, the distinction between the two persists, and will continue to be enormously important in the foreseeable future").

68. Prosecutor v. Tadic, Case No. IT-94-1-A, Decision on Defence Motion for Interlocutory Appeal on Jurisdiction 19 94-137 (Int'l Crim. Trib. for the Former Yugoslavia Oct. 2, 1995). 2013).

69. See Antonio Cassese et al., Cassese's international Criminal Law 65-70 (3d ed.

70. See Baxter, supra note 44, at 519-20 (discussing the negotiation process at Geneva).

71. See, e.g., L. C. GREEN, THE CONTEMPORARY LAW OF ARMED CONFLICT 304-05 (1993).

72. On the nature of the classification scheme, see generally Milanovic \& Hadzi-Vidanovic, supra note 34 , at 256 .

73. See Corn, supra note 12 , at 268 (noting that extending the privilege along with Common Article 3 was viewed by the delegates as simply unacceptable). 
ternational concern, relevant to the international community and subject to its laws. On the other hand, the drafters (apparently) wanted to say that what the government does with the rebels after the war is over-and whether it recognizes them as morally equal - is a matter of domestic sovereignty and is not a matter of international concern. ${ }^{74}$ The state can do what it wants in this regard. Few bother to ask whether this framework is conceptually coherent. In fact, the notion of professional belligerency is hard-wired into the concept of armed conflict, since armed conflict is a contest between parties with professional belligerents operating on their behalf. The concept of belligerency is baked into our understanding of armed conflict and the drafters attempt to separate the two notions (belligerency and armed conflict) under the guise of regulating NIACs is borderline incoherent from a conceptual point of view.

Consequently, there may be a role for the privilege of combatancy in a wider number of armed conflicts than usually assumed. The criteria for combatancy are functional in nature and can be applied against both government forces and rebels. There are substantial policy negatives if the privilege is denied to rebels by fiat in all situations. Indeed, previous generations of international lawyers were well aware of these implications and were comparatively more comfortable viewing rebels in some non-international conflicts as legitimate belligerents. A full analysis of this historical development now follows.

\section{THE NINETEENTH-CENTURy ClASSIFICATION SCHEME}

In contrast to today's international law, the nineteenth century and its historical antecedents had a much richer classification scheme for understanding and analyzing internal armed conflict. Somewhere along the way, much of this classification system has been lost, at least among contemporary treatise writers who slavishly hew to a rigid and narrow dichotomy between international and non-international armed conflicts. ${ }^{75}$ The following Part aims to recapture that lost complexity. Section II.A examines recognitions of belligerency, a process by which states can voluntarily recognize a rebel force as an official belligerent engaged in an armed conflict. This process recognizes the transition point for rebel forces when they approach de facto statehood; as the rebels gain territory and engage in the trappings of governance, they are often recognized as official belligerents on that basis. ${ }^{76}$ Although this was traditionally conceived as a recognition voluntarily conferred on rebels by their state, it should be remembered that third-party states are capable of recognizing rebels as belligerents - a process that occurred during the American Civil War-and at least some scholars view recognition as a duty. ${ }^{77}$ Section II.B excavates the richer classification

74. Mégret's analysis notices the tension as well. See generally Frédéric Mégret, Should Rebels Be Amnestied?, in JUS POST BELLUM: MAPPING THE NORMATIVE FOUNDATIONS 519 (Carsten Stahn et al. eds., 2014) (noting that rebels in non-international armed conflicts are entitled to humanitarian protections, but not to the privilege of belligerency).

75. See, e.g., CRAWFORD, supra note 10, at 154 (noting that "arguments in support of a uniform application of the laws of armed conflict have existed for almost as long as there has been a law of armed conflict").

76. See SIVAKUMARAN, supra note 13, at 9-19.

77. See, e.g., IAN BROWNLIE, PRINCIPLES OF PUBlic INTERNATIONAL LAW 85-93 (7th ed. 
scheme for armed conflicts used by previous generations of international lawyers. Finally, Section II.C applies this evidence to an interpretation of Common Article 3(4), which preserved the existing law regarding the status of internal armed conflicts. Since belligerents in NIACs were sometimes viewed as legitimate, it is logical to conclude that Common Article 3 preserved-rather than destroyed — that basic scheme.

\section{A. Recognition of Belligerency}

Any discussion of the recognition of belligerency should begin with the U.S. Civil War. In his canonical codification of the laws of war, Lieber viewed soldiers on both sides of the conflict as morally equal professional soldiers. ${ }^{78}$ The Lieber Code therefore supports the functional view of the privilege of belligerency: what matters is whether the troops are complying with the laws of war, not whether they are fighting on behalf of a de jure sovereign. First, Lieber's definition of armed conflicts is not limited to contests between states; he defined war as a "protracted physical contest between large numbers.", Soldiers were professionals, who fought on behalf of the collective, which itself bore the consequences of their action. ${ }^{80}$ Lieber's rejection of a fully statecentric model should come as no surprise since he was codifying the laws of war for use in a civil war; the first application of the Lieber Code was for a non-international conflict. If the privilege of belligerency was inapplicable in non-state armed conflicts, one would expect to find evidence in the Code that Confederate soldiers were unprivileged combatants.

True, the Lieber Code provides in Section 10 that prosecutions for treason are permitted at the end of the civil war. ${ }^{81}$ This issue will be analyzed in greater depth in Part III, which will argue that the privilege of combatancy in civil war prohibits prosecutions for murder under domestic law but allows for prosecutions for loyalty-based offenses like treason for those who have defied the state. However, two points are in order here. First, Section 10 allows for prosecutions for treason for rebel leaders and commanders, though nothing is said regarding rank-and-file troops. If indeed the privilege is absent, the prosecutions for all members of the rebel forces ought to be permitted, yet Article 154 is limited by its terms to rebel commanders. ${ }^{82}$

Second, Article 154 should not overshadow Article 153, which offers a more subtle analysis of the relationship between parties to an armed conflict:

Treating captured rebels as prisoners of war, exchanging them, concluding of car-

2008); HERSCH LAUTERPACHT, RECOGNITION IN INTERNATIONAL LAW 175 (1st paperback ed. 2013).

78. JOHN FABIAN WITT, LINCOLN'S CODE: THE LAWS OF WAR IN AMERICAN History 227 (2012). Witt suggests that Lieber may have been inclined to apply the laws of war to the South in part because he had lived in the South, owned slaves at one point, and his late son had fought for the South. Id.

79. Francis Lieber, Law and Usages of War, Lecture at Columbia Law School (1861) (on file with Milton S. Eisenhower Library, Johns Hopkins University, Baltimore, Md., Francis Lieber Papers, Box 2, Folders 16-18).

80. Lieber Code, supra note 27, art. 20.

81. Id. art. 154 .

82. Id. 
tels, capitulations, or other warlike agreements with them; addressing officers of a rebel army by the rank they may have in the same; accepting flags of truce; or, on the other hand, proclaiming Martial Law in their territory, or levying war-taxes or forced loans, or doing any other act sanctioned or demanded by the law and usages of public war between sovereign belligerents, neither proves nor establishes an acknowledgment of the rebellious people, or of the government which they may have erected, as a public or sovereign power. Nor does the adoption of the rules of war toward rebels imply an engagement with them extending beyond the limits of these rules. It is victory in the field that ends the strife and settles the future relations between the contending parties. 83

As this passage makes clear, the application of the laws of war during a civil war does not entail a recognition that the rebels constitute a state or a legitimate de jure sovereign. This is what is meant when paragraph 4 of Common Article 3 states that the provision does not change the legal status of the parties to the conflict. Application of the laws of war does not transform a rebel force into the army of a new sovereign power. But it is an exaggeration to jump from this commonsensical assertion to the much broader claim, so often repeated today, that the legal architecture of "combatancy" is irrelevant to non-international armed conflicts. ${ }^{84}$ The truth is somewhere short of that.

The truth is that the dividing line between internal conflicts and international armed conflicts is blurry and grey, hardly the black-and-white categorical distinction that some assume it to be. ${ }^{85}$ In the past, the fault line between these concepts was mediated by a particular legal doctrine, the recognition of belligerency. ${ }^{86}$ Current analysis of the recognition of belligerency has fallen into disrepair. ${ }^{87}$ The doctrine existed to mediate the confused netherworld between the two types of armed conflict. In general, the doctrine held that a state can recognize an armed group as a belligerent party to an armed conflict. This recognition triggered some of the machinery of international law, in particular the requirements of the law of neutrality. So, if a foreign state were to aid the rebels, this would violate the third state's duty of neutrality and would render them cobelligerents of the rebels.

The process of recognizing a rebel force as an official belligerent is often described as a voluntary process - a strategic decision made by a host government that confers official belligerent status on rebels, but only if the host state decides to engage in the recognition. ${ }^{88}$ For the same reason, jus post bel-

83. Id. art. 153

84. See, e.g., MELZER, supra note 5, at 323; SolIS, supra note 5, at 191; Dormann, supra note 5 , at $269-70$.

85. Another example is the U.S. armed conflict against Native Americans in the nineteenth century. The Indian chief Plenty Horses was acquitted of murder on the grounds that his killing of a U.S. army soldier was excused by the privilege of combatancy during armed conflict. See SolIS, supra note 5, at 30-34; William WinTHROP, MiLiTARY LAW AND PRECEDENTS 778 (Gov't Printing Office 2d ed. 1920) (1886).

86. But see Sasha Radin, The Current Relevance of the Recognition of Belligerency, in ARMED CONFlict and INTERNATIONAL LAW: IN SEARCH OF THE HuMAN FaCE 115 (M. Matthee et al. eds., 2013).

87. U.K. Ministry of Defence, Manual of the Law of ARMED CONFLiCt 384 (2004) ("The doctrine has declined to the point where recognition of belligerency is almost unknown today."); Baxter, supra note 44, at 520 (noting that the institution had fallen into disuse).

88. See, e.g., WILlIAM EDWARD HALL, INTERNATIONAL LAW 29 (Oxford, Clarendon Press 
lum scholars often talk of the need and efficacy of offering amnesty to rebels after a civil war, though again this decision is couched as an entirely voluntary one. ${ }^{89}$ Though there are strong reasons for granting amnesty, the reasons are often stated in moral, political, and philosophical terms-not strictly legal arguments. But there are substantial reasons to view the recognition of belligerency in non-voluntary terms. ${ }^{90}$

Consequently, the doctrine of recognition is slightly more complicated than usually assumed. True, a government engaged in an armed conflict has the ability to recognize, or refuse to recognize, its enemy as a formal belligerent. However, that recognition might be implicit or explicit. The U.S. Civil War is illustrative of this point. ${ }^{91}$ Although Lincoln never formally declared the Confederacy a belligerent power, the Supreme Court held in the Prize Cases that he had implicitly done so with various actions, including the naval blockades and seizure of naval vessels. ${ }^{92}$ As such, the court took judicial notice that the Confederacy was a belligerent power and that the President could not now claim that the laws of war were inapplicable to the resolution of the Prize Cases. ${ }^{93}$ Consequently, the Supreme Court ruled that the Confederacy was a belligerent power.

Second, recognition of belligerency was not purely within the power of the host state. Third party states also implicitly recognized the confederacy as a formal belligerent by various actions of their ports with regard to Confederate naval ships. ${ }^{94}$ Recognition of a rebel group as a formal belligerent was therefore not entirely within the control or discretion of the executive branch, nor even within the control of the government itself. ${ }^{95}$ Third-party states figured

1880) (linking recognition of belligerency with state self-interest); Milanovic \& Hadzi-Vidanovic, supra note 34 , at 263 ("The malleability and vagueness of the criteria suggested that the recognition of belligerency was always more a matter of political expediency than a matter of law.").

89. See, e.g., Mégret, supra note 74, at 521; see also Protocol Additional to the Geneva Conventions of 12 August 1949, and Relating to the Protection of Victims of Non-International Armed Conflicts (Protocol II) art. 6(5), June 8, 1977,1125 U.N.T.S. 609 [hereinafter Additional Protocol II] ("At the end of hostilities, the authorities in power shall endeavour to grant the broadest possible amnesty to persons who have participated in the armed conflict, or those deprived of their liberty for reasons related to the armed conflict, whether they are interned or detained.").

90. See, e.g., LAUTERPACHT, supra note 77, at 175 (concluding that the recognition of belligerency, like the recognition of statehood, is a "duty imposed by the facts of the situation," because the contesting parties "are legally entitled to be treated as if they are engaged in a war waged by two sovereign States"); STEPHEN C. NEFF, WAR AND THE LAW OF NATIONS: A GENERAL HISTORY 261 (2005) (referring to the decision as a duty but noting that in practice the "logic was not strictly adhered to" and the practice "was to allow foreign countries a fairly large measure of discretion in this delicate area").

91. See 2 L. OPPENHEIM, INTERNATIONAL LAW: A TREATISE 204 \& n.2 (H. Lauterpacht ed., 7th ed. 1952) (stating that civil war between states in a federal system is an international war even in the absence of a recognition of belligerency from third-party states).

92. 67 U.S. (2 Black) $635,666-67,669$ (1863) ("When the party in rebellion occupy and hold in a hostile manner a certain portion of territory; have declared their independence; have cast off their allegiance; have organized armies; have commenced hostilities against their former sovereign, the world acknowledges them as belligerents, and the contest a war."). For analysis, see Baxter, supra note 44, at 518-19. See also LAUTERPACHT, supra note 77, at 193 n. 1 (listing cases where the U.S. Supreme Court applied international law to conflicts involving non-state actors).

93. Prize Cases, 67 U.S. at 670 (stating that a proclamation of blockade is "conclusive evidence" of a state of war).

94. See NEFF, supra note 90, at 259-60; Radin, supra note 86, at 122.

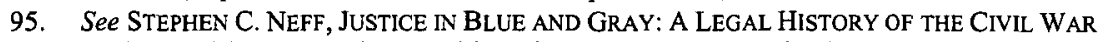
18-19 (2010) (noting British and French recognition of the Confederacy as a belligerent power). 
into the calculus. ${ }^{96}$ That third-party states should figure into the process of recognizing belligerency is not as surprising as it sounds. Under general principles of law, third-party states already yield enormous power through their determination of which entities constitute states. ${ }^{97}$ Regardless of whether one adopts the constitutive or declaratory view of state recognition, it is undeniable that recognition by a third-party is one part of the process by which states come into being (in addition to meeting the objective requirements for statehood) ${ }^{98}$ Consequently, third-party states may recognize a rebel group as the government of a newly formed state (in the case of secessionist war), or they may recognize the rebel group as the legitimate government of the parent state, provided that they control enough territory and meet other relevant criteria. ${ }^{99}$

Something very similar happened in Libya in 2013, when some countries moved quickly to recognize rebels fighting against Colonel Gaddafi's government as the new government of Libya. ${ }^{100}$ Combined with the territorial control exercised by the rebels, third-party state recognition helped solidify the rebels' claims to de jure sovereignty. ${ }^{101}$ It should therefore come as no surprise that a lesser form of recognition - that of belligerency-should in part be controlled by third-party states as well. ${ }^{102}$ This again shows that the dividing line between an international and non-international armed conflict is blurry and messy. ${ }^{103}$

\section{B. The Nineteenth-Century Categories}

The major nineteenth-century publicists generally viewed civil wars as standing in a liminal space between mere insurrections and international armed conflicts. Not all civil disturbances fell within this liminal category, and certainly localized rebellions were entirely a matter of sovereign concern. However, civil disturbances and rebellions could ripen into a full-blown civil war that triggered the application of at least part of the machinery of international law governing conflicts. ${ }^{104}$ The strain of thought was the natural extension of prin-

\footnotetext{
96. Id. at 167-69; Radin, supra note 86 , at 128 .

97. LAUTERPACHT, supra note 77 , at 26.

98. Id. at 67.

99. Id. at 87 .
}

100. See Alan Cowell \& Steven Erlanger, France Becomes First Country to Recognize Libyan Rebels, N.Y. TIMES, Mar. 10, 2011 , http://www.nytimes.com/2011/03/11/world/europe/11 france.html.

101. The U.N. General Assembly eventually voted to recognize the National Transitional Council as the legitimate representative of the country. See G.A. Res. 66/1, U.N. Doc. A/RES/66/1 (Sept. 16, 2011).

102. See ThOmas Alfred Walker, THE SCIENCE OF INTERnational LaW 115-16 (London, C.J. Clay \& Sons, Cambridge Univ. Press 1893).

103. Note that Farer concluded that civil wars should not always be excluded from the definition of intemational armed conflict as that term is used in the Geneva Conventions. See Farer, supra note 35 , at 72 (describing the text of the Geneva Convention on this issue as "Delphic").

104. See, e.g., HENRY W. Halleck, InTERnational LAw: OR Rules Regulating the INTERCourse of States in Peace and War 332-33 (San Francisco, H. H. Bancroft \& Company 1861); see also NEFF, supra note 90, at 251 ("Before civil conflicts could be considered as true wars, a crucial conceptual step was necessary: of somehow placing insurgents on a legal par with the government that they were rebelling against, at least in matters relating to the conflict itself . . . In this area, perhaps more than in any other in the legal history of war, state practice took the leading role, with doctrine following demurely in its wake. The crucial step was the recognition that insurgent groups could, and should, be treated as independent bodies on a de facto basis, provided that they met certain criteria 
ciples that can be traced back as far as Vattel in the eighteenth century. ${ }^{105}$ The publicists had different ways of putting the point, though the general approach-civil wars as standing in between rebellions and international conflicts - was the same. ${ }^{106}$

For example, Wheaton defined a public war as a "contest by force between independent sovereign States." ${ }^{107}$ However, following Grotius, Wheaton defined civil wars as a "mixed" war with elements of public conflict and private conflict. ${ }^{108}$ Civil wars were public because the government stood on one side of the conflict; they were also private because the enemy fought against the authority of the state rather than on behalf of it. ${ }^{109}$ The "mixed" status of a civil war meant that the armed conflict was not simply a matter of sovereign concern and that some international law governed the conflict because "the general usage of nations regards such a war as entitling both the contending parties to all the rights of war as against each other, and even as respects neutral nations." 110 Lorimer concluded that when a soldier commits crimes in his private capacity, states could withdraw their recognition of belligerency, which would "depriv[e] the war of its public character" and would place combatants "at the mercy of the municipal laws of the other" and "prisoners might then be punished as rebels." 111 But this was only possible when a soldier committed an act "in his private capacity." 12 Essentially, this explains why a soldier who vio-

such as the control of territory and the discharging of governmental functions.").

105. Vattel viewed conflicts on a scale of increasing intensity: commotion, sedition, insurrection, and finally rebellion or civil war. See EMMERICH DE VATTEL, THE LAW OF NATIONS §§ 289-90, at 421 (Joseph Chitty ed., Philadelphia, T. \& J. W. Johnson 1844) (1758). Vattel viewed the laws of war as applicable to civil wars when a state is divided between two factions. Id. $\S 294$, at 425 ("[I]t is very evident that the common laws of war-those maxims of humanity, moderation, and honour, which we have already detailed in the course of this work, - ought to be observed by both parties in every civil war. For the same reasons which render the observance of those maxims a matter of obligation between state and state, it becomes equally and even more necessary in the unhappy circumstance of two incensed parties lacerating their common country."). The distinction between rebellion and civil war was whether the rebels had a just cause for resisting their own government. In the former they did not; in the latter they did. See NEFF, supra note 90, at 254-55. This just cause distinction appears earlier in in the mideighteenth century in Wolff. See 2 Christian WOLFF, Jus GENTIUM METHODO SCIENTIFICA PeRTRaCTATUM \$1011, at 514 (Joseph H. Drake trans., Oxford, Clarendon Press 1934) (1749) ("[S]ince rebellion has an unjust cause, but civil war a just cause, a rebellion is not a civil war and civil war is not rebellion; consequently subjects who stir up a civil war are not rebels.").

106. See, e.g., 3 F. DE MARTENS, TRAITÉ DE DROIT INTERNATIONAL 185 (Alfred Léo trans., Paris, Librarie A. Marescq Ainé A. Chevalier-Marescq 1887) ("Cependant lorsqu'une insurrection se transforme en une guerre entre deux parties belligérantes régulièrement organisées, quand elle est conduit des deux côtés par de véritables gouvernements, au moyen d'armées qui respectent les lois et les usages des guerres internationals, une pareille guerre civile prend le caractère d'une guerre international ..." ["An insurrection is transformed into a war between belligerent parties regularly organized, when it is conducted by both sides by veritable governments, by armies that respect the laws and usages of international wars; such a civil war takes the character of an international war . ..."]). For a discussion, see NEFF, supra note 90 , at 250.

107. HENRY WhEATON, ElEMENTS OF INTERNATIONAL LAW 364 (William Beach Lawrence ed., Little, Brown \& Co. 1855) (1836).

108. Id. at 365 . For the Grotian view, see HUGO GROTIUS, ON THE LAW OF WAR AND PEACE 91 (Francis W. Kelsey trans., Oxford Univ. Press 1925) (1625).

109. WHEATON, supra note 107 , at 365 .

110. Id.

111. 2 JAMES LORIMER, THE INSTITUTES OF THE LAW OF NATIONS 76 (Edinburgh \& London, William Blackwood \& Sons 1883).

112. Id. at 75-76. 
lates the laws of war can be punished before a military tribunal and therefore loses the privilege of belligerency.

Westlake held similar views, noting the fundamentally bifurcated nature of civil wars. ${ }^{113}$ They were, on the one hand, war in the sense of international law; but, on the other hand, also treason. ${ }^{114}$ For Westlake,

[t]he truth is that a great insurrection with a real government at its head may have both characters. It will be war for the purpose of the neutrality of the powers which recognise the insurgents as having belligerent rights, and even the government against which it is directed may and ought, for the sake of humanity, to treat it as war while the struggle continues, though if and when it has been put down the internal law of that government will not thereby be prevented from regarding it as treason. ${ }^{115}$

This is fully in line with the standard view of the hybrid or mixed theory of the U.S. Civil War-a police action and a war against a belligerent at the same time.$^{116}$ But it was clear that a party in a full civil war held belligerent rights, ${ }^{17}$ as long as the civil conflict took on the character of a public war. ${ }^{118}$ Neutral countries were in a position to confer belligerent status when they viewed the civil conflict as being the functional equivalent of an inter-state war. ${ }^{119}$

Under this view, soldiers fighting in a rebellion that ripened into a full civil war, recognized as such by the international community, were regarded as legitimate belligerents. ${ }^{120}$ If the rebels lost the war, the winning government was capable of prosecuting them for treason, though this did not diminish the fact that when the war ripened from a mere insurrection to a full civil war, the rebels in some sense graduated from mere thugs and criminals into professional soldiers, entitled to all the respect that international law conferred on soldiers. ${ }^{121}$ All soldiers were deserving of humane treatment and the protection of

113. 2 JOHN WESTLAKE, INTERNATIONAL LAW 1 (1907).

114. Id. at 2 .

115. Id.

116. See NEFF, supra note 95 , at 15; WITT, supra note 78, at 151 ("By establishing a blockade and declaring southern privateers to be pirates, Lincoln had insisted that the preservation of the Union could be a war and a criminal law enforcement action at the same time, that there was no need to choose either paradigm once and for all.").

117. See WESTLAKE, supra note 113 , at 1 ("[W]ar is the state or condition of governments contending by force. Governments are here mentioned and not states, because the laws of war belong equally to insurgents not yet recognised as a state but recognised as having belligerent rights, which they could not be if they did not possess a government.") (emphasis omitted); see also Milanovic \& HadziVidanovic, supra note 34 , at 263.

118. See, e.g., 2 JAN HELENUS Ferguson, MANUAL OF INTERNATIONAL LAW, FOR THE USE OF NAVIES, COLONIES AND CONSUlates 258 (The Hague, Martinus Nyhoff 1884) ("[W] here the contest assumes the character of a public war, as refined and recognized by the Law of Nations, it is the general usage of other States to concede to both parties the rights of war, so far as regards the law of blockage, of contraband, etc.").

119. Lorimer held similar views, regarding both the U.S. Civil War and the Latin American wars of independence between 1816 and 1825 as being transformed in a limited sense into "international wars" by virtue of the "recognition of belligerency by neutral Powers." See LORIMER, supra note 111, at 32.

120. Phillimore believed that civil or revolutionary actions could ripen into a full war and he included a lengthy discussion of the application of international law to civil wars. See 3 ROBERT PHILlimore, COMMENTARIES UPON INTERNATIONAL LAW 148, I52-53 (Philadelphia, T. \& J.W. Johnson \& Co. 1857).

121. See NEFF, supra note 90, at 257-58 ("This meant that captured opponents were entitled to 
the law while in captivity, a forerunner of today's POW status. ${ }^{122}$

\section{Reading Common Article 3 in Context}

What emerges from the nineteenth-century literature is a clear view that civil wars could be more than just internal rebellions; if sufficiently war-like, they triggered the application of international law and the protections implicit in them. ${ }^{123}$ Rebels recognized as belligerents were entitled to the rights of belligerency understood under international law. Why would the international community engage in the state practice that generated this rule? After all, it seems odd that states would concede that civil wars were subject to international regulation-an apparent conflict with the self-interest of states. However, as some scholars have noted, this approach came with an advantageous flipside. ${ }^{124}$ If rebels were legitimate belligerents fighting in an armed conflict, they could not be charged as mere criminals for their battlefield killings. However, by extension of the war paradigm, they could be detained on the basis of mere membership in the rebel army without requiring proof of any particular acts of belligerency. ${ }^{125}$

Furthermore, the same logic applied to membership-based targeting as well: rebel soldiers could be killed on the basis of their membership alone in the rebel army without any more specific evidence of their threatening nature. This represents a substantial benefit in extending the international law of war paradigm to these situations. In the modern context, there is substantial criticism of the shift to the more liberal detention and targeting practices of the war paradigm in order to vanquish an enemy of the state, ${ }^{126}$ but it is a legal and strategic move firmly rooted in historical practice.

It is against this backdrop that one needs to understand the negotiations that led to the adoption of The Hague Convention of 1907 and the Geneva Conventions of 1949. If Common Article 3 changed nothing, as scholars argue,

be treated as prisoners of war, so that they could only be subjected to a non-punitive detention, to prevent them from rejoining and augmenting their forces. They could not be prosecuted as criminals (except in the marginal case in which they were accused of having committed breaches of the international rules on the conduct of war itself) .... It was generally conceded, however, that these constraints on the government's conduct only applied during the struggle itself. After the disturbances had ended, the government could proceed to prosecute the rebels as criminals if it wished.").

122. As Lorimer put it in his Institutes of the Law of Nations, captured soldiers were no longer citizens of any state-they became "citizens of the world." See LORIMER, supra note 111, at 72 ("Though separated, for the time being, from any political community, they once more belong to humanity and to themselves.").

123. See, e.g., William EdWARD Hall, INTERNATIONAL LaW pt. 1, ch. 1, 85 (Oxford, Clarendon Press 1880) ("When a community in attempting to separate itself from the state to which it belongs, sets up a govemment and carries on hostilities in a regular manner, it shows in the course of performing these acts a more complete momentary independence than those communities . . . of which independence is qualified .... Frequently however it is admitted, through what is called recognition as a belligerent, to the privileges of law for the purposes of the hostilities in which it has engaged in order to establish its legal independence.").

124. See NEFF, supra note 90 , at 257 (discussing membership-based detention).

125. Id.

126. See, e.g., Mary Ellen O'Connell, Unlawful Killing with Combat Drones: A Case Study of Pakistan, 2004-2009, in SHOOTING TO KIll: THE LAW GOVERNING LeTHAL FORCE IN CONTEXT 263 (Simon Bronitt et al. eds., 2012). 
then we need to fall back on the existing law before Geneva, i.e., the nineteenth century framework. International lawyers generally tend to ignore the nineteenth century when engaging in their historical understanding of the field. ${ }^{127}$ If indeed the extension of basic principles of humanitarian law to non-internal armed conflicts in Common Article 3 "did not change the status of the parties, ${ }^{, 128}$ then one needs to understand the status quo prior to the first half of the twentieth century: that rebels were capable of being combatants. Consequently, the view that the concept of "combatant" is utterly foreign to non-internal conflicts is an exaggeration. ${ }^{129}$

How then to understand the limit in Common Article 3 that the protections "do not change the status of the parties"? ${ }^{130}$ The more sensible interpretation is that the provision codified the intuition that entitlement to humanitarian protections (under Common Article 3) did not entail that rebel movements were legitimate and entitled to recognition as formal state entities. The phrase also implied, by corollary, that if government forces were successful in their fighting, they could then prosecute the rebels for treason (since Common Article 3 did not imply by logical deduction that their struggle against the government was legitimate in some macro legal and political sense). Although the law of war under Common Article 3 protects rebels, the nature of those protections does not prohibit their post bellum prosecution for treason, since Common Article 3 had no effect on the legitimacy of their struggle. In a sense, Common Article 3(4) has more to do with jus ad bellum internum (agnosticism with respect to the legitimacy of the conflict) rather than the jus in bello interno. This is entirely consistent with recognizing the privilege of combatancy in the noninternational context.

How does one square the claim that rebels could have a privilege of belligerency with the claim that a victorious government could prosecute them for treason? Although this sounds like a contradiction, a careful analysis of the domestic prohibition on killing, its relationship to the combatant's privilege, and the historical evidence, shows that prosecution for treason is entirely consistent with the privilege, once its appropriate contours are understood. Simply put, murder and treason are different crimes that penalize conceptually distinctive normative violations, as the following Part will explain.

\section{POST-BELLUM PROSECUTIONS FOR WARTIME CONDUCT}

The following Part develops the distinction between prosecution for loyalty-based offences and prosecution for murder. It concludes that even if the privilege of combatancy were to attach to rebels in some non-international armed conflicts, a state could still prosecute rebels and insurgents for violating a duty of loyalty to their state. This demonstrates that a "non-international priv-

127. See David Kennedy, International Law and the Nineteenth Century: History of an Illusion, 65 NORDIC J. INT'L L. 385 (1996) (noting that public international lawyers recognize Vattel and Grotius as precursors but generally ignore nineteenth century sources).

128. See Third Geneva Convention, supra note 25, art. 3(4).

129. See SoliS, supra note 5, at 191; Newton, supra note 7, at 343; Goodman, supra note 5.

130. See Third Geneva Convention, supra note 25, art. 3(4). 
ilege of combatancy" is consistent with the underlying policy rationale for the orthodox position, which seeks to preserve the right of states to prosecute vanquished rebels. In other words, recognizing non-international privilege of combatancy does not require foregoing a criminal law response after the end of a civil war-which is precisely the sticking point that is often cited for denying the existence of a non-international privilege of combatancy. The distinction between murder and treason is neither thin nor contrived; it is, rather, necessary in order to properly conceptualize the relationship between a citizen and his or her state. ${ }^{131}$ Section III.A explains the distinction between prosecuting rebels for treason or murder and Part $\mathrm{V}$ applies this insight to current asymmetrical conflicts.

\section{A. Prosecution for Loyalty-Based Offenses}

Although rebellions can ripen into full-blown civil wars that trigger the machinery of international law, this is not to say that the privilege prevents the victorious government from taking any and all action against the vanquished rebels. Rebels are responsible for their decision to violate their duty of loyalty to the government and as such can be prosecuted for treason and other loyaltybased crimes. ${ }^{132}$ However, soldiers in bona fide civil wars are combatants entitled to the privilege of combatancy and should not be prosecuted for murder. Although the privilege extinguishes the criminal liability associated with their killing of enemy soldiers in wartime, it does not extinguish their violation committed against the government. ${ }^{133}$

The current literature on the privilege of combatancy in non-international armed conflict misses this subtle distinction and falsely claims that the privilege is completely inapplicable in all non-international armed conflicts. Although the distinction between prosecutions for murder and prosecutions for treason is a fine-grained distinction, it is conceptually justified and accords with historical practice, even if our knowledge of that historical practice has been glossed over by the repeated assertion in modern textbooks that the privilege never applies in non-international conflicts. ${ }^{134}$

First, consider the conceptual arguments. Recognizing the distinction between murder and treason recognizes the essential symmetry in the privilege's application in international and non-international armed conflicts; professional soldiers are professional soldiers regardless of the type of conflict.

131. For a general discussion of the crime of treason, see GEORGE FLETCHER, LOYALTY: AN ESSAY ON THE MORALITY OF RELATIONSHIPS 47-52 (1993); Stephen P. Garvey, Are Attempts Like Treason?, 14 NEw CRIM. L. REV. 173, 203 (2011) (describing the violation of the duty of loyalty to fellow citizens).

132. See Corn, supra note 12 , at 266 (explaining that "participation in hostilities against lawful government authority was and remains almost universally regarded as perhaps the most serious crime against the state: treason").

133. See, e.g., The Prize Cases, 67 U.S. (2 Black) 635, 667 (1863) ("They claim to be in arms to establish their liberty and independence, in order to become a sovereign State, while the sovereign party treats them as insurgents and rebels who owe allegiance, and who should be punished with death for their treason.") (emphasis added).

134. See WESTLAKE, supra note 113, at 2 (acknowledging that individuals fighting on behalf of non-state actors can be treated as parties to a war). 
Lawful combatants in international conflicts may assert the privilege and consequently cannot be prosecuted for murder for killing enemy combatants. An enemy government cannot prosecute them for treason either, though that has nothing to do with the application of the Convention - it has to do with the fact that the soldier owes no duty of loyalty to the enemy government. In contrast to the rebel who violates an oath of loyalty to his own government, the international soldier defies no relationship with the enemy government when he takes up arms against an international enemy. So the privilege works the same way in both contexts; what changes is the existence or non-existence of the duty of loyalty. Finally, consider how the privilege works in the context of an international conflict when one soldier crosses sides to fight for the enemy. Consider an American citizen who leaves the United States to fight for Russia during a hypothetical World War III. If U.S. forces capture the American citizen during battle (while fighting for the Russian Army as a uniformed solider), the privilege of combatancy would prevent the United States from prosecuting him for murder but would not prevent the United States from charging him with treason for violating his duty of loyalty to his own government. ${ }^{135}$

Second, historical practice supports the distinction between murder and treason prosecutions. ${ }^{136}$ Generally speaking, there are few historical examples where victorious governments have engaged in universal criminal prosecutions of all rebel soldiers for domestic murder-an outcome one would expect more frequently if the orthodox view of the privilege were correct. ${ }^{137}$ Instead, the more typical practice is for rebel soldiers to be granted amnesty for their behavior during the rebellion. ${ }^{138}$ In some cases rebel leaders are charged with treason, though in other cases a victorious government will decide for reasons of expediency to issue an amnesty for rebel leaders as well, ${ }^{139}$ perhaps as a carrot to convince them to lay down their arms. ${ }^{140}$ The current literature generally assumes that granting such amnesties is a discretionary choice, on the part of the controlling government, to be made on the basis of the exigencies of the jus post bellum situation. ${ }^{141}$ However, the more nuanced answer is that in a bona

135. As it happens, the U.S. government did not generally prosecute American citizens of German ancestry who fought in the German Army in World War II. In cases where the United States did prosecute American nationals, they were members of the U.S. armed forces who deserted from their military service. See, e.g., Court Weighs Pleas for Treason Appeal, N.Y. TIMES, Oct. 4, 1952, at 24 (describing conviction of Martin James Monti for treason for taking an American military plane during the invasion of Italy and flying it into German territory).

136. The Lieber Code is explicit in reserving the right of successful governments to prosecute former rebels for treason. See Lieber Code, supra note 27, art. 154.

137. See VATTEL, supra note $105, \S 290$, at 423 (noting that in cases where the number of revolters is high, "clemency becomes a duty in the sovereign. Shall he depopulate a city, or desolate a province, in order to punish her rebellion? Any punishment, however just in itself, which embraces too great a number of persons, becomes an act of downright cruelty").

138. See Mégret, supra note 74 , at 524 (noting that amnesties are often linked to the "humanitarian project" even if the exact link is somewhat obscure).

139. This was the case during the U.S. Civil War. See NEFF, supra note 95, at 222 ("There had never been much doubt that ordinary Confederate soldiers and civilians would not, in practice, be subject to prosecution."); WITT, supra note 78, at 268.

140. See Mégret, supra note 74 , at 525 (explaining the practice of providing amnesty in exchange for surrendering arms).

141. Antonio Cassese, Should Rebels Be Treated as Criminals? Some Modest Proposals for 
fide civil war, the privilege prevents the government from prosecuting rebels for murder but it may prosecute them for their illegitimate and illegal decision to take up arms against the government. ${ }^{142}$

For some observers, the decision to fight against a government (treason) and killings committed in furtherance of that fight (murder) cannot be so easily separated. They all flow from the same source, after all, the internal armed conflict against the government; they are all war. In reality, though, the distinction between them is structurally sound and mirrors the relationship between $j u s$ ad bellum and jus in bello in international conflicts. International lawyers are already comfortable separating out these two legal frameworks; indeed they often demand that they be kept separate. The jus ad bellum framework applies to the decision to go to war and asks whether it was just and complies with basic principles of international law and the general prohibition against the use of force in the absence of self-defense or Security Council authorization. In contrast, the jus in bello framework focuses on how the armed conflict is carried out. Even though both involve the armed conflict, it is possible to separate out the why from the how. The distinction between treason and murder tracks the same fault line. In prosecuting a rebel for treason, a court is convicting him for the illegitimate and unjust decision to fight against his own government, a kind of internal jus ad bellum. ${ }^{143}$ The actual killings performed in battle become analogous to an internal jus in bello, a separate legal question that can be quarantined from the prior question of whether the decision to exercise force is lawful or not. ${ }^{144}$

The fact of the matter is that there are few examples of civil war prosecutions of all soldiers on the losing side for the domestic crime of murder. ${ }^{145}$ Such a practice would be predicated on the view that a civil war is made up of thousands - or even millions - of cases of individual murder, a description at stark odds with our common conception of war as being both quantitatively and

Rendering Internal Armed Conflicts Less Inhumane, in REALIZING UTOPIA: THE FUTURE OF INTERNATIONAL LAW 519, 522 (Antonio Cassese ed., 2012) (recognizing the need for amnesty and immunity but conceding no state practice for curtailing right of states to engage in post-conflict prosecutions). Mégret notes a tension with Cassese's "clear inclination toward recognizing a privilege of belligerency in non-international armed conflicts." See Mégret, supra note 74, at 523 n.17; see also Baxter, supra note 44 , at 526-27 (supporting the voluntary view because every state "must thus ask itself whether it desires to continue to apply its law for the maintenance of public order to all persons within the territory of the state or whether it is willing to grant an immunity from prosecution and a protected position under international law to those who fight against it").

142. But see Baxter, supra note 44 , at 526 (concluding that a government can treat a rebel as a "murderer" consistent with Common Article 3).

143. On the notion of an internal jus ad bellum, see Bugnion, supra note 37, at 168; Frédéric Mégret, Civil Disobedience and International Law: Sketch for a Theoretical Argument, 46 CAN. Y.B. INT'L L. 143 (2010); Frédéric Mégret, Le Droit International Peut-il Etre un Droit de Résistance? Dix Conditions pour un Renouveau de l'Ambition Normative International, 39 ÉTUDES INTERNATIONALES 39 (2008); and Mégret, supra note 74, at 538 (introducing a notion of $j u$ ad rebellium).

144. See generally Kjell Anderson, The Universality of War: Jus ad Bellum and the Right to Peace in Non-International Armed Conflicts, in THE CHALLENGE OF HUMAN RJGHTS: PAST, PRESENT AND FUTURE 52, 52 (David Keane \& Yvonne McDermott eds., 2012) (discussing jus ad bellum in noninternational contexts).

145. See generally Michel VeutheY, GuÉRILla ET Droit HuManitaire (1983) (describing the growing attitude of legitimacy or acceptance conferred by the international community on some guerrilla movements). 
qualitatively different from peacetime murder. It simply is extraordinary to, for example, disaggregate the U.S. Civil War into 750,000 cases of individual murder. ${ }^{146}$ This misses the irreducibly collective reality of warfare. ${ }^{147}$

One comeback to this objection is that only the rebels have engaged in murder, while government soldiers have engaged in lawful killings. ${ }^{148}$ This much is true. It has also inspired some scholars to argue for an asymmetrical privilege of combatancy in non-international conflicts. ${ }^{149}$ Under this view, government soldiers are protected by the privilege while rebel soldiers are not, thus making only rebel soldiers liable for murder convictions. ${ }^{150}$ Although there is nothing incoherent about this possibility, it depends on how one views state practice regarding post-bellum convictions. ${ }^{151}$ Of course, states would never prosecute their own soldiers (for regular acts of belligerency) after prevailing in a civil war, since the state is the winning party to the conflict. The more apt situation to test the thesis would be a government party that loses an armed conflict and is replaced by the rebels who form a new government. ${ }^{152}$ If third-party states cite international law as prohibiting a new government from prosecuting the soldiers of the original government for garden-variety acts of belligerency, this would constitute supporting evidence of the asymmetrical view. The problem, of course, is that it would also be evidence of the symmetrical view expressed here, i.e., that both government forces and rebels are immune from prosecutions for regular murder.

The example of the U.S. Civil War is pertinent here. Rank-and-file Confederate soldiers were not prosecuted for their mere participation in the war. ${ }^{153}$

146. See J. David Hacker, Recounting the Dead, N.Y. TIMES: OPINIONATOR (Sept. 20, 2011, 9:38 PM), http://opinionator.blogs.nytimes.com/2011/09/20/recounting-the-dead (revising the death toll of the Civil War upwards on the basis of historical research).

147. On the collective reality of warfare, see GEORGE P. FLETCHER, ROMANTICS AT WAR: GLORY AND GUILT IN THE AGE OF TERRORISM 43 (2002) (describing international criminal law as the union of individualist and collectivist patterns of thought). See generally GERRY J. SIMPSON, LAW, WAR AND CRIME: WAR CRIMES TRIALS AND THE REINVENTION OF INTERNATIONAL LAW (2007) (arguing that war crimes as a paradigm require collective action).

148. For a description of this view, see Henderson, supra note 32, at 150 (noting that governments have a positive right under international law to engage in a non-international armed conflict against internal enemies). Henderson also notes that in cases where non-state actors have been recognized as legitimate belligerents, the armed conflict in question has been recognized as international in nature. Id; see also Mégret, supra note 74, at 533.

149. See Ian Henderson \& Bryan Cavanagh, Guest Post: Military Members Claiming SelfDefence During Armed Conflict-Often Misguided and Unhelpful, OPINIO JURIS (July 8, 2014, 8:00 AM), http://opiniojuris.org/2014/07/08/guest-post-military-members-claiming-self-defence-armed -conflict-often-misguided-unhelpful.

150. See, e.g., WILLIAM H. BOOTHBY, THE LAW OF TARGETING 433 (2012) (concluding that government forces in NIAC "are permitted to use lawful force" but also noting that it "has always been difficult to find a single descriptor that can be applied both to those fighting for, and those fighting against, the government in such conflicts").

151. State refusal to prosecute government forces could stem from the international privilege, domestic authorization, or obvious prosecutorial discretion.

152. An example of this would be the opposition forces in Afghanistan, including the Northern Alliance, which ousted the Taliban from power with American and coalition military assistance and formed a new government. See Paul Salopek, Rebel Fighters Enter Kabul, CHI. TRIB., Nov. 13, 2001, http://www.chicagotribune.com/chi-0111130325novl3-story.html.

153. See also NEFF, supra note 90 , at 255-56 (citing British statutes defining American rebels as engaging in treason but conceding that criminal trials were impractical). 
At least part of the reason for their immunity was based on principles of reciprocity and comity; with so many Union soldiers in captivity in the South, Lincoln was mindful that providing good treatment to Confederate soldiers was important to ensure like protection for Union soldiers imprisoned in the South. Of course, captured Union soldiers were often mistreated, as the case of Andersonville prison makes clear. ${ }^{154}$ However, it is clear that no Confederate soldiers were charged, and that even prosecutions against rebel leaders for launching the war were abandoned as the demands of reconstruction took center stage. ${ }^{155}$

Indeed, when prosecutions were considered during the Civil War, it was always for treason and never for murder simpliciter. ${ }^{156}$ And these prosecutions were limited to situations where a duty of loyalty was owed to the government. As John Witt explains in his history of the laws of war during the Civil War, citizens of border states were prosecuted for treason for joining the Confederate army, an action that Union lawyers "did not treat as criminal at all when done by residents of the states that voted to secede." 157 Simply put, regular soldiers in the Confederacy were viewed as professional soldiers who were engaged in the process of belligerency that came with their citizenship in the southern states. While the leaders of the rebel movement could have been charged with treason, there simply was no question of charging regular Confederate soldiers for murder for each act of killing during battlefield engagements. To assume that the government could have charged them as such is to confuse crime and war. $^{158}$

The nineteenth-century publicists writing on the law of war generally spoke of post-conflict prosecutions in the language of treason, not murder in the general sense. ${ }^{159}$ For example, Ferguson noted that in insurrection that ripens into a civil war belligerent rights were "superadded to those of sovereignty" and at the conclusion of the conflict the winning government could subject the rebels to prosecution as "traitors." 160 Hall noted that it would be impractical to treat such huge numbers of rebels as mere criminals. ${ }^{161}$ In cases where interna-

154. See WITT, supra note 78 , at 298 (noting that 12,912 men died at Andersonville due to inhumane conditions). The commander responsible for the prison, Captain Henry Wirz, was later prosecuted before a military commission. Id. at 299-301.

155. Id. at 268,322 .

156. Id. at 268-69.

157. Id.

158. The distinction between the two concepts is complex. See generally George P. Fletcher, The Law of War and Its Pathologies, 38 CoLuM. HuM. RTS. L. REV. 517 (2007) (describing the different frameworks and licit forms of action invoked by labels of crime and war, and the danger of hybrid forms).

159. Again, this outcome is consistent with the general eighteenth century and nineteenth century view. For example, Vattel claimed that when a sovereign was victorious in a civil war, he was required to grant amnesty to the rebel soldiers but permitted to "except from the amnesty the authors of the disturbances, - the heads of the party: he may bring them to a legal trial, and punish them, if they be found guilty." VATTEL, supra note $105, \S 294$, at 426 . That being said, Vattel thought that punishing the rebel leaders was more appropriate in a rebellion than a full-blown civil war, thus suggesting that even the opposition leaders should receive clemency at the end of a civil war. Id.

160. See FERGUSON, supra note 118 , at 258.

161. See HALl, supra note 123 , at $27-28$ ("As soon, it is said, as a considerable population is arrayed with the professed object of attaining political ends, it resembles a state too nearly for it to be possible to treat individuals belonging to such population as criminals; it would be inhuman for the enemy to execute his prisoners; it would be still more inhuman for foreign states to capture and hang the 
tional law recognized the permissibility of prosecuting former rebels, it was generally for treason, not murder. ${ }^{162}$ Indeed, oaths of loyalty were incredibly important for understanding the relationship between a belligerent and the state. By the nineteenth century, it was already well established that declaring that no quarter will be given was contrary to the law of nations. When a soldier was captured in battle but the capturing state was unwilling or unable to house the soldier, the only other option was to release the prisoner "on parole"-a promise by the soldier that he would not rejoin the battle at a later point in time. ${ }^{163}$ If the soldier broke this solemn oath and was subsequently recaptured during a second battle, he could be prosecuted by enemy courts for violating his duty of loyalty (his promise) to the capturing state. ${ }^{164}$ This shows how deeply engrained the principles of loyalty and oaths were in the deep structure of the law of war. ${ }^{165}$ The concepts of loyalty and oath mediated the relationship between individual belligerents and the states they fought for.

All of this raises the deeper question of the basic structure of the privilege of combatancy-a woefully under-theorized question in standard international doctrine. It is generally understood that the privilege transforms what would otherwise be an unlawful killing into a lawful act. ${ }^{166}$ But the exact interplay between the doctrine of international law and the domestic criminal law is somewhat mysterious. As a matter of international law doctrine, the privilege is regarded as a prohibition under international law that prevents a state from engaging in prosecutions. ${ }^{167}$ But that is far different from saying that the criminal law does not apply. How does a doctrine from international law transform the criminal law? One possibility is that the doctrine includes a corresponding defense that operates within criminal law. ${ }^{168}$ But if so, it is not codified in crimi-

crews of war-ships as pirates; humanity requires that the members of such a community shall be treated as belligerents, and if so there must be a point at which they have a right to demand what confessedly must be granted."). However, Hall treats this as a principle of humanity, not a principle of international law, calling it a "concession of pure grace." Id. at 28.

162. Id.

163. See Hague Convention of 1899 , supra note 39 , art. 11; see also WESTLAKE, supra note 113 , at 65 (discussing Hague Regulations on parole).

164. Id.

165. See, e.g., 1 JAMES Wilson, THE WORKS OF THE Honourable James WiLson 312-13 (Philadelphia, Bronson \& Chauncey at Lorenzo Press 1804) (concluding that a citizen is incapable of dissolving the bounds of allegiance between himself and the sovereign and is therefore responsible for betraying that duty of loyalty and obedience).

166. Lieber Code, supra note 27, art. 57.

167. See Robert K. Goldman \& Brian D. TITTEMORE, ASIL TASK Force on TERrorism, UNPRIVILEGED COMBATANTS AND THE HOSTILITIES IN AFGHANISTAN: THEIR STATUS AND RIGHTS UNDER INTERNATIONAL HUMANITARIAN AND HUMAN RIGHTS LAW 2 (2002) ("This privilege is in essence a license to kill or wound enemy combatants, destroy other enemy military objectives and cause incidental civilian casualties. A lawful combatant possessing this privilege must be given prisoner of war status upon capture and immunity from criminal prosecution under the domestic law of his captor for his hostile acts that do not violate the laws and customs of war."); Melzer, supra note 11, at 306 (explaining that the absence of privilege exposes a combatant to the "full force of domestic criminal law").

168. The relationship between the privilege of combatancy and the criminal law defense is raised, though not analyzed, in the Office of Legal Counsel memorandum on the killing of Anwar alAulaqi (based on research reportedly performed by Professors David Barron and Martin Lederman). See Memorandum from David J. Barron, Acting Assistant Attorney Gen., to the Attorney Gen. on Applicability of Federal Criminal Laws and the Constitution to Contemplated Lethal Operations Against Shaykh Anwar al-Aulaqi 17 (July 16, 2010) (concluding that the federal murder statute implicitly incorporates 
nal law, unless one refers to the public authority justification, though it is unclear if the public authority justification incorporates the privilege or simply mirrors the privilege. ${ }^{169}$ The other possibility is that the privilege is implicit in the law of war, and that the law of war is not limited to international law but rather is directly part of the common law, which explains why the privilege is a function of domestic law as well. ${ }^{170}$ Although there is some historical support for the idea that the law of war was regarded as part of the common law, it is uncomfortable to speak of a common law of war that is somehow distinct from international law. ${ }^{171} \mathrm{~A}$ final possibility is to adopt a monist view of international law, thus making it comparatively easier to explain why a prohibition at the international level can reach down and operate as a defense in municipal law.

To review, the law of war permits states to prosecute the enemy after an armed conflict, though we need to be subtle about asking which types of prosecutions are permitted. In the course of any conflict, whether IAC or NIAC, states can prosecute the enemy for deliberately killing civilians. In the course of a NIAC, a state can prosecute rebels for battlefield killings of enemy combatants, though the proper charge depends on whether the rebels are entitled to the combatant's privilege or not. If they are entitled to the privilege, they can only be prosecuted for a loyalty-based offence, like treason, and they are immune from prosecution for murder. On the other hand, if they are not entitled to the privilege because they fail to meet the functional standards for the privilege, they can be prosecuted for murder and treason. If the NIAC involves a foreign non-state actor that owes no duty of loyalty to the government, they can be prosecuted for murder only if they fail to meet the standards for the privilege of combatancy. This result can be expressed in the following table:

\begin{tabular}{|l|l|l|}
\hline \multicolumn{3}{|c|}{ CRIMINAL LIABILITY FOR BATTLEFIELD KLLINGS } \\
\hline & $\begin{array}{l}\text { Domestic } \\
\text { Non-State Actors }\end{array}$ & $\begin{array}{l}\text { Foreign } \\
\text { Non-State Actors }\end{array}$ \\
\hline $\begin{array}{l}\text { Compliance with law of armed } \\
\text { conflict (and entitled to } \\
\text { the privilege of combatancy) }\end{array}$ & Treason & Immunity \\
\hline $\begin{array}{l}\text { Non-compliance with law of } \\
\text { armed conflict (and not entitled to } \\
\text { the privilege of combatancy) }\end{array}$ & $\begin{array}{l}\text { Treason } \\
\text { and murder }\end{array}$ & Murder \\
\hline
\end{tabular}

all relevant justifications, including the public authority justification).

169. For a discussion of the public authority justification in criminal law, see MODEL PENAL CODE $§ 3.03(1)(d)$; Paul H. Robinson \& Michael T. CAHILl, CRIMINal Law 319 (2d ed. 2012) (stating that an "actor receives a defense if his conduct "is required or authorized by the law governing the armed services or the lawful conducts of war ...."').

170. This view, if correct, would suggest that recent references to the "U.S. common law of war" in the al-Bahlul habeas litigation are not misplaced. See al-Bahlul v. United States, 767 F.3d 1 (D.C. Cir. 2014) (holding, under plain error review, that the U.S. common law of war supports the authority of the government to prosecute al-Bahlul for conspiracy, but not material support for terrorism, before a military commission).

171. See Hamdan v. Rumsfeld, 548 U.S. 557, 613 (2006). 


\section{THE PRIVILEGE OF COMBATANCY IN MODERN ASYMMETRICAL CONFLICTS}

Having established in Part III that the privilege of combatancy might apply in some non-international armed conflicts, this Article will now apply this insight to modern asymmetric conflicts against non-state actors, specifically the conflict with al-Qaeda. ${ }^{172}$ This Part will explain why members of the U.S. armed forces enjoy the privilege, whereas members of al-Qaeda do not. This is because members of al-Qaeda do not fulfill the standard criteria for belligerency: carrying arms openly, wearing fixed emblems, and following the laws and customs of war. ${ }^{173}$ As such, they can be prosecuted for murderunder domestic law-for their acts of belligerency, ${ }^{174}$ or for war crimes when they violate specific prohibitions in the laws of war (such as targeting civilians or engaging in acts of perfidy). In a similar armed conflict against an enemy that met the criteria for lawful belligerency, neither prosecutions for murder nor prosecutions for treason would be permitted unless the individuals involved were citizens or residents of the United States. Non-citizen members of a nonstate actor have no duty of loyalty against the United States and could not be prosecuted for taking up arms against them. Criminal sanctions against them would be limited to their terrorist activities or other violations of the laws of war (directed against civilians). ${ }^{175}$ A full analysis follows.

\section{A. The Privilege Applies in the Armed Conflict Against al-Qaeda}

Consider the U.S. armed conflict with al-Qaeda, as well as other modern conflicts between a state and a foreign non-state actor. These conflicts depart substantially from the type of full-blown civil wars discussed in Part I and II, thus requiring a significant degree of logical extension of principles to a new context. The nineteenth century paradigm applied the bulk of international legal regulation to rebellions that ripen into full civil wars. ${ }^{176}$ Contests between two warring governments within a state were regarded as sufficiently analogous to an armed conflict between two international states to trigger the same basic

172. For a general discussion of this issue, see generally Joseph P. "Dutch" Bialke, Al-Qaeda \& Taliban Unlawful Combatant Detainees, Unlawful Belligerency, and the International Laws of Armed Conflict, 55 A.F. L. REV. 1 (2004) (summarizing the four conditions of belligerency that need to be satisfied in order to trigger the combatant's privilege).

173. See supra Sections I.A-B.

174. Although unprivileged combatants are guilty of murder under domestic law, they are not guilty of committing "war crimes" as an offense under the law of nations. The United States originally charged Canadian Omar Khadr with committing "murder in violation of the law of war" for killing an American soldier in Afghanistan. As several commentators have correctly noted, Khadr's unprivileged killing of an American soldier is a case of domestic murder but not an international crime per se. For a discussion of this issue, see Joseph C. Hansen, Murder and the Military Commissions: Prohibiting the Executive's Unauthorized Expansion of Jurisdiction, 93 MINN. L. REV. 1871, 1872 (2009). See also BAXTER, supra note 10 , at $52-53$ (concluding that a hostile action by unprivileged belligerents is characterized as a violation of international law only "from a fundamental confusion between acts punishable under international law and acts with respect to which international law affords no protection"). However, it should also be noted that Baxter assumed that unprivileged "secret agents" like the saboteurs in Ex Parte Quirin, 317 U.S. 1 (1942), were subject to prosecution before military courts (even though their crimes were domestic in nature). See BAXTER, supra note 10, at 52.

175. See supra Parts IV-V.

176. See supra Section II.A. 
paradigm of legal regulation. ${ }^{177}$ Consequently, soldiers in these conflicts were defined as bona fide combatants whose killings constituted lawful belligerency. ${ }^{178}$ Their actions would not be prosecuted as murder, though they could be charged with treason for their unlawful and unjust decision to violate their oath of loyalty to the government. ${ }^{179}$ However, none of these conditions apply to the armed conflict with al-Qaeda, which operates outside the territory of the government that it fights, and which owes no duty of loyalty to the government it challenges. Like much of the current legal terrain regarding the war on terror, the present question requires application of old law to new facts. The purpose of Part II was not to find an old framework that fits the facts of modern asymmetrical conflicts. Rather, the goal was to problematize the simplistic and overly categorical statement that the privilege of combatancy has no role to play in non-international armed conflict. Having demonstrated that this is an exaggeration and that no such categorical exclusion exists, the slate is clean to permit careful reasoning about the appropriate role for the privilege in modern asymmetrical conflicts, such as the war against al-Qaeda. The present Section takes up that challenge.

Applying the basic principles outlined above, it seems plausible to suggest that the privilege could apply in a conflict between a state and a modern non-state actor-a classic example of what nineteenth-century scholars would have regarded as a "mixed war" between a public state enjoying sovereignty and a private entity. ${ }^{180}$ The fact that the private entity operates more commonly outside the territory of the public state makes little difference to the analysis. The most important element is the functional inspiration for the nineteenth century view that was in place when Common Article 3 preserved it - that some non-international conflicts take on the character of an international conflict, and ought to be treated as such, if they involve two independent entities involved in a military contest. ${ }^{181}$ In this sense, the nineteenth century view was supported by a rejection of formalism in favor of a deep commitment to functionalism: if the contest functioned like a de facto international conflict (such as between the Union and the Confederacy) then it could and perhaps should be treated as such by the international community. ${ }^{182}$

177. See SIVAKUMARAN, supra note 13 , at 515-20.

178. See supra notes 104-126 and accompanying text.

179. For a discussion of loyalty-based offences in the law of war, see generally RICHARD BAXTER, The Duty of Obedience to the Belligerent Occupant, in BAXTER, supra note 10, at 7, 16-23. Residents under a belligerent occupation owe a duty of loyalty to the occupying power, although the source of this obligation is contested. See id. at 8-16.

180. See WHEATON, supra note 107 , at 365 .

181. If the armed conflict is functionally equivalent to an international conflict, then third parties should be under a duty to recognize this fact, and it is erroneous to think of the recognition as being purely discretionary. See LAUTERPACHT, supra note 77, at 175 (arguing that the duty is imposed by the facts of the situation).

182. This was certainly Vattel's view. He concluded that "when a nation becomes divided into two parties absolutely independent, and no longer acknowledging a common superior, the state is dissolved, and the war between the two parties stands on the same ground, in every respect, as a public war between two different nations." VATTEL, supra note $105, \S 295$, at 427 . In that case, both factions view the other as "rebels" because "there exists in the state two separate bodies, who pretend to absolute independence, and between whom there is no judge ... [and] decide their quarrel by arms, as two different nations would do." Id. The obligation to observe the law of war in a civil war was therefore "absolute" 
The armed conflict with al-Qaeda bears many of the hallmarks of such a conflict. It involves an international conflict between a sovereign state and a non-state actor with distinctive military and political goals. Furthermore, the international community views the two entities as locked in an international struggle and must decide which side to support, thus triggering elementary principles inherent in the law of neutrality, the very principles that governed the recognition of belligerency in the nineteenth century. ${ }^{183}$ While the Taliban supported al-Qaeda and refused to declare its neutrality, other states have supported the United States and offered assistance in the conflict. ${ }^{184}$ These factors suggest that the privilege could apply to asymmetric armed conflicts with non-state actors-at the very least for government forces fighting on behalf of the state. ${ }^{185}$

\section{B. Al-Qaeda Fighters Fail the Functional Standard}

Whether the non-state actor's fighters are eligible for the privilege depends on whether the non-state actor fulfills the functional requirements for lawful belligerency: a command structure, a fixed emblem, open arms, and general compliance with the laws and customs of war. Although al-Qaeda arguably meets the first criterion, it does not meet the other three. ${ }^{186}$ Terrorist organizations typically make no effort to distinguish themselves from the civilian population, nor do they limit their targeting to military objectives. ${ }^{187}$ Consequently, al-Qaeda personnel are not entitled to the privilege of combatancy, but not because the conflict is non-international. Fighters for al-Qaeda are not eligible for the privilege because their armed group does not meet the functional criteria. Killings performed by unprivileged belligerents constitute domestic murder in the jurisdiction where the crime occurs, thus triggering the local machinery of criminal justice. ${ }^{188}$ However, none of this changes whether government forces on the other side of the conflict are eligible for the privilege.

One could well imagine a future conflict between a state and a non-state actor that complies with the functional criteria for lawful belligerency. Perhaps

and "indispensably binding on both parties." Id. at 427.

183. Bradley and Goldsmith first suggested that the law of neutrality was applicable to the armed conflict with al-Qaeda. See Curtis A. Bradley \& Jack L. Goldsmith, Congressional Authorization and the War on Terrorism, 118 HARV. L. REV. 2047, 2112 (2005) (discussing the doctrine of cobelligerency). But see Kevin Jon Heller, Goldsmith Responds About "Co-Belligerency," OPINIO JURIS (Oct. 18, 2010, 8:49 PM), http://opiniojuris.org/2010/10/18/goldsmith-responds-about-co-belligerency (criticizing the extension of rules from IAC, including the law of neutrality, to NIAC).

184. See Bradley \& Goldsmith, supra note 183 , at 2112 (discussing the duty of neutrality with regard to non-state actors).

185. See Henderson, supra note 32, at 150. For a discussion of combatant status in noninternational conflicts, see also Richard V. Meyer, The Privilege of Belligerency and Formal Declarations of War, in TARGETED KILLINGS: LAW \& MORALITY IN AN ASYMMETRICAL WORLD 183, 213 (Claire Finkelstein et al. eds., 2012).

186. Ambos argues in a recent paper that al-Qaeda is not sufficiently organized or hierarchical to be a party to an armed conflict. See Kai Ambos \& Josef Alkatout, Has "Justice Been Done"? The Legality of Bin Laden's Killing Under International Law, 45 ISR. L. Rev. 341, 347-50 (2012). But see Jens David Ohlin, The Duty to Capture, 97 MNN. L. REV. 1268, 1283 (2013) (concluding that al-Qaeda is organized with a command structure, though not necessarily a linear one).

187. Additional Protocol II, supra note 89, art. 1.

188. See BAXTER, supra note 10 , at 53 . 
the hypothetical group is less interested in adopting the tactics of international terrorism and more interested in fighting in accordance with international standards, namely by deploying uniformed personnel who carry their arms openly and target only enemy combatants. ${ }^{189}$ In this hypothetical conflict, the underlying principles of belligerency suggest that it would be possible to apply the privilege of belligerency to both sides of that conflict: the government forces and the extraterritorial non-state soldiers who oppose them. This argument becomes more plausible the more organized the non-state actor is. To the extent that the non-state actor has something approaching a government, then the reasons for applying the principles of international warfare become stronger, just as they did for rebels fighting in a civil war in the nineteenth century paradigm. ${ }^{190}$ In this scenario, soldiers for the non-state actor should be charged neither with murder nor treason, since they owe no duty of loyalty to the government they oppose. However, they can be summarily killed in battle according to the laws of targeting, detained until the end of hostilities pursuant to international humanitarian law or domestic implementing legislation, and perhaps even detained prospectively consistent with international human rights law. ${ }^{191}$ They may also be subject to punishment for violating any applicable oath of loyalty to their host state if their participation in the armed conflict is inconsistent with the directives and interests of their own sovereign.

\section{The Privilege of Combatancy in Covert ACtions}

In the case of the United States, military actions in asymmetrical conflicts are increasingly likely to include covert and unacknowledged uses of force. ${ }^{192}$ Covert action and clandestine operations are distinct concepts and should not be confused. Clandestine operations are designed to be secret in the sense that the operators take action to avoid detection. In contrast, covert actions are unacknowledged in the sense that the deploying government refuses to admit that the actors are working on behalf of the state. Some operations are both clandestine and covert at the same time because the deploying state hopes the military action remains secret and will refuse to acknowledge the force after it is discovered. This Article concerns covert actions authorized under Title 50 or otherwise unacknowledged operations.

The United States relies heavily on covert deployments for multiple reasons. ${ }^{193}$ First, host governments may have given permission for the U.S. military to operate on their territory, on the condition that the United States does

189. See NEFF, supra note 90 , at 251 (noting that Islamic law in the Middle Ages distinguished between ordinary criminals and bughat, persons who "fought for some kind of doctrine or higher cause than mere personal enrichment").

190. See, e.g., MARTENS, supra note 106, at 185.

191. The issue of security detention authorized under IHRL is discussed in Ryan Goodman, The Detention of Civilians in Armed Conflict, 103 AM. J. INT'L L. 48 (2009).

192. Cf. Wall, supra note 15 , at 140 .

193. For a cogent analysis of the reasons (both legitimate and illegitimate) for prior U.S. reliance on covert action, see W. MICHAEL REISMAN \& JAMES E. BAKER, REGULATING COVERT ACTION: PRACTICES, CONTEXTS, AND POLICIES OF COVERT COERCION ABROAD IN INTERNATIONAL AND AMERICAN LAW (1992). 
not acknowledge that they are operating in that area. ${ }^{194}$ This might be beneficial for the host government if an overt use of military force would upset local constituents, thus triggering political problems for the host government. ${ }^{195}$ Second, the host state may demand that the attacking force operate covertly because the permission to operate is based on an explicit deal that no one wants to acknowledge. ${ }^{196}$ The nature of the deal might include military assistance to the host state's own military campaign, which the host government may not feel free to acknowledge. ${ }^{197}$ Third, an attacking force may wish to attack covertly if they believe that their jus ad bellum arguments for violating state sovereignty are weak and therefore do not wish to acknowledge the operation. ${ }^{198}$ For all of these reasons, military actions against extraterritorial terrorist organizations are increasingly conducted using covert and unacknowledged military action. The paradigm of military force in Pakistan and Yemen (covert force that is generally known but officially unacknowledged) may become the paradigm for future security operations. ${ }^{199}$

Because these operations are covert, they often include a significant CIA presence. ${ }^{200}$ In particular, the CIA has argued for institutional primacy in drone operations-maintaining a significant fleet of its own remotely piloted vehicles-in order to preserve the covert and unacknowledged nature of the use of force. $^{201}$ This generated a substantial buildup of CIA paramilitary forces. ${ }^{202}$ Critics have complained that the ever-growing paramilitary capabilities of the CIA have distracted it from its primary mission of intelligence gathering and analysis. ${ }^{203}$ More importantly, others have argued that the CIA's involvement in a large percentage of foreign military strikes has hindered transparency and

194. For a discussion of these issues, see Marty Lederman, Secrecy, Nonacknowledgement, and Yemen, JUST SECURITY (Feb. 26, 2014), http://justsecurity.org/7454/secrecy-nonacknowledgement -yemen (claiming that "a state will have reason not to officially acknowledge its involvement in a certain action, even if the action is no longer secret in any real sense, i.e., where it has been widely reported and where it is widely assumed (and perhaps even unofficially leaked) that the state in question was involved"); see also Wilson v. CIA, 586 F.3d 171, 197-99 (2d Cir. 2009) (discussing reasons for nonacknowledgement).

195. This issue is discussed in Jack Goldsmith, Two Notes on Secrecy $v$. Transparency in the National Security World, LAWFARE (Oct. 3, 2013, 12:24 PM), http://www.lawfareblog.com /2013/10/two-notes-on-secrecy-v-transparency-in-the-national-security-world.

196. This may have been the case with regard to U.S. military force in Pakistan. See MARK MAZZETTI, THE WAY OF THE KNIFE: THE CIA, A SECRET ARMY, AND A WAR AT THE ENDS OF THE EARTH 196 (2013) (discussing the United States" "Faustian" bargain with Pakistan).

197. Id.

198. See Goldsmith, supra note 195 (arguing that administration officials might be inclined to proceed with a military strike covertly if they believe the action may not be consistent with the U.N. Charter).

199. Id.

200. See Greg Miller, CIA Remains Behind Most Drone Strikes, Despite Effort to Shift Campaign to Defense, WASH. POST, Nov. 25, 2013, http://www.washingtonpost.com/world/national -security/cia-remains-behind-most-drone-strikes-despite-effort-to-shift-campaign-to-defense/2013/1 1/25 /c0c07a86-5386-1 le3-a7f0-b790929232el_story.html.

201. Id.

202. Id.

203. See, e.g., Select Committee on Intelligence, Additional Prehearing Questions for Mr. John O. Brennan upon His Nomination to Be Director of the Central Intelligence Agency, U.S. SENATE (Feb. 7, 2013), http://www.intelligence.senate.gov/130207/prehearing.pdf. 
accountability for targeted killings. ${ }^{204}$ Many critics have suggested that full control over U.S. drone operations should be transferred from the CIA to JSOC. ${ }^{205}$ It appeared for a time that the Obama Administration largely agreed with that assessment, although it remains unclear whether that assessment will be transformed into bureaucratic reality. ${ }^{206}$ At the moment, the CIA continues to play an important role in drone deployment in foreign theaters where force remains unacknowledged. $^{207}$

Several scholars have argued that the United States should transfer control of drone operations from the CIA to JSOC because the latter are uniformed members of the regular armed forces and therefore eligible for the privilege of combatancy. ${ }^{208}$ CIA personnel, without the privilege of combatancy, would be violating the domestic law of the country in which they operate. ${ }^{209}$ Although a local prosecution of a CIA agent in Yemen for violating Yemeni domestic criminal law is rather unlikely, it could be possible if civil war produces a change in the central government, ${ }^{210}$ which as of 2015 seems likely. ${ }^{211}$ Under this argument, JSOC should retain as much control over drones as possible.

The net result is that the Obama administration has deployed force in operations that can only be described as truly hybrid in nature. ${ }^{212}$ The raid to

204. Cf. Report of the Special Rapporteur on the Promotion and Protection of Human Rights and Fundamental Freedoms While Countering Terrorism, U.N. Doc. A/HRC/25/59 (Feb. 28, 2014) (by Ben Emmerson) (concluding that CIA involvement in drone strikes hinders transparency).

205. See, e.g., Micah Zenko, Policy Innovation Memorandum No. 31: Transferring CIA Drone Strikes to the Pentagon, COUNCIL ON FOREIGN RELATIONS (Apr. 2013), http://i.cfr.org/content /publications/attachments/PIM_Drones_Zenko_Final_4_16_13.pdf (arguing for enhanced accountability if drone strikes are authorized pursuant to Title 10).

206. See Mark Mazzetti, Delays in Effort to Refocus C.I.A. from Drone War, N.Y. TiMEs, Apr. 5, 2014, http://www.nytimes.com/2014/04/06/world/delays-in-effort-to-refocus-cia-from-drone -war.html (discussing the slow pace of the CIA's response to President Obama's stated goal of decreasing CIA involvement in drone operations).

207. Some sources have suggested that congressional officials blocked the migration of authority from the CIA to JSOC. See Eric Schmitt, Congress Restricts Drones Program Shift, N.Y. TIMES, Jan. 16, 2014, http:/www.nytimes.com/2014/01/17/us/politics/congress-restricts-drones-program-shift.html.

208. See, e.g., Mary Ellen O'Connell, Professor of Law, Univ. of Notre Dame, Testimony Before the Subcomm. on Nat'l Sec. and Foreign Affairs (Apr. 28, 2010), http://www.fas.org/irp /congress/2010_hr/042810oconnell.pdf (concluding that only members of the U.S. armed forces are entitled to the combatant's privilege); Solis, supra note 3; Andrew Burt \& Alex Wagner, Blurred Lines: An Argument for a More Robust Legal Framework Governing the CIA Drone Program, 38 YALE J. INT'L L. ONLINE 8-12 (2012), http://www.yjil.org/docs/pub/o-38-burt-wagner-blurred-lines.pdf.

209. Burt \& Wagner, supra note 208, at 11 ; see also Jens David Ohlin, Is Jus in Bello in Crisis?, 11 J. INT'L CRIM. JUST. 27, 42 (2013) (arguing that CIA members are not privileged because they do not carry arms openly or display distinctive signs); Kevin Jon Heller, Let's Call Killing al-Awlaki What It Is-Murder, OPINIO JURIS (Apr. 8, 2010, 10:34 PM), http://opiniojuris.org/2010/04/08/lets-call -killing-al-awlaki-what-it-is-murder ("I doubt many CIA field operatives carry their arms openly and distinguish themselves from the civilian population.").

210. See Kevin Jon Heller, Is the CIA in the Drone Kill Chain? (Answer: Likely), OPINIO JuRIS (Mar. 17, 2013, 6:41 PM), http://opiniojuris.org/2013/03/17/is-the-cia-in-the-drone-kill-chain-answer -likely (suggesting in the comments section that Yemen could prosecute CIA officers under domestic law in the absence of the combatant's privilege).

211. See Shuaib Almosawa \& Rod Nordland, U.S. Fears Chaos as Government of Yemen Falls, N.Y. TIMES, Jan. 22, 2015, http://www.nytimes.com/2015/01/23/world/middleeast/yemen-houthi-crisis -sana.html.

212. The issue is discussed in Philip Alston, The CIA and Targeted Killings Beyond Borders, 2 HARV. NAT'L SECURTY J. 283, 346-47 (2011) (discussing the relationship between JSOC and CIA operations). 
kill Osama Bin Laden was only the most famous example: the President authorized a covert action, under Title 50, using members of the armed forces (Navy SEALs) who conducted the assault. ${ }^{213}$ In that case, the Navy SEALs were formally under the direction of CIA Director Leon Panetta, who reported to the President, even though the Navy SEALs are usually deployed by the Department of Defense under Title 10. ${ }^{214}$ This issue is crucial because drone strikes, even if conducted by uniformed JSOC personnel, can be conducted through Title 50 and remain covert. ${ }^{215}$

The following Part argues that military personnel engaged in unacknowledged deployments are not entitled to the privilege of combatancy, despite the fact that they wear uniforms and fight for a military organization that honors the laws and customs of warfare. ${ }^{216}$ The attempt to solve the "privilege problem" by switching authority to JSOC does not work. ${ }^{217}$ The privilege does not run to these uniformed troops because the lack of state acknowledgment frustrates the state's ability to assert the privilege on their behalf. The following Section will explain this argument by interrogating fundamental requirements of combatancy that are rarely scrutinized in the academic literature. Consequently, Section V.A will examine how the open arms requirement is generally analyzed in commentaries to the Geneva Conventions and will show that the traditional commentaries have viewed the requirement far too literally and have ignored conceptual understandings of the requirement. ${ }^{218}$ Section V.B will argue that the privilege is collective, not individual, i.e., that the privilege can only be asserted by a collective fighting group on behalf of an individual, rather than by an individual directly. Section V.C will argue that this view is necessitated by the fact that the principle of distinction requires that troops identify themselves as belonging to a particular fighting organization, rather than as a combatant simpliciter. Section V.D will analyze under what conditions a state's retroactive acknowledgment of the force might cure these defects. Finally, Section V.E will specifically consider how to analyze the open arms requirement when the weapon system in question involves the mixed deployment of CIA and military personnel in drone operations.

The structure of the argument involves three elements that are all mutually supporting. Combined together, the open arms requirement, the collective nature of the combatant's privilege, and the principle of distinction (and its associated prohibition on perfidy) all highlight the extreme pressure that the use of unacknowledged force places on the basic structure of the law of war. Spe-

213. See Wall, supra note 15 , at 85 .

214. See Chesney, supra note 15 , at 539-41.

215. See also Lederman, supra note 194 ("[A]s far as the law is concerned, both the CIA and U.S. Department of Defense can engage in activities that are not officially acknowledged . ...").

216. For a general discussion of the use of uniformed forces in U.S. covert action, see Jennifer D. Kibbe, Covert Action, Pentagon Style, in THE OXFORD HANDBOOK OF NATIONAL SECURITY INTELLIGENCE 569, 583 (Loch K. Johnson ed., 2010) (discussing danger to the United States' reputation when the government deploys regular armed forces, as opposed to the CIA, in covert operations).

217. Some of these issues are analyzed in Todd C. Huntley \& Andrew D. Levitz, Controlling the Use of Power in the Shadows: Challenges in the Application of Jus in Bello to Clandestine and Unconventional Warfare Activities, 5 HARV. NAT'L SECURITY J. 461, 490 (2014).

218. See, e.g., ICRC, COMMENTARY TO THIRD GENEVA CONVENTION, supra note 43, at 61 . 
cifically, the law of war requires a transparent link between the combatant and the state on whose behalf the combatant fights. That link transforms what would otherwise be a simple act of murder into a lawful act of belligerency. In the words of the Lieber Code, a nation will "advance and retrograde" with its soldiers on the battlefield, ${ }^{219}$ and the results produced in the battlefield are accepted as binding on the nation. ${ }^{220}$ Without that link, a combatant is just an individual engaged in garden-variety murder under domestic law-an unprivileged belligerent. As this Part demonstrates, unacknowledged force is inconsistent with the deeper principles that provide the conceptual foundation for the combatant's privilege.

\section{A. The Carrying-Arms-Openly Requirement at Geneva}

The requirement that military forces must carry arms openly to be eligible for prisoner of war status is codified in Article 4 of the Geneva Convention. ${ }^{221}$ Although there is no direct statement that this is also one of the requirements for privileged belligerency, it is inferred based on the function of POW status (which is inconsistent with a criminal prosecution while in detention). ${ }^{222}$ At Geneva there appears to have been little discussion of the exact nature of the requirement. ${ }^{223}$ Perhaps delegates considered it obvious. Or, perhaps, the requirement's codified origin from the 1899 and 1907 Hague Regulations meant that the delegates were simply carrying forward an element of existing law and therefore it did not require extensive analysis or discussion. ${ }^{224}$

The commentaries to the Geneva Convention all interpret the requirement in a physical sense and the debates are limited to questions regarding weapons that are generally not worn outside of the body. ${ }^{225} \mathrm{~A}$ rifle is usually carried slung around the shoulder, but a grenade might be transported in a backpack. $^{226}$ Commentators fret over whether this hypothetical soldier meets the requirement-a set of banal concerns based on the various ways that soldiers walk and pack their equipment between military engagements.

The ICRC commentary by Jean Pictet draws a distinction between carrying arms "openly" versus carrying them "visibly" or "ostensibly."227 Arms can still be carried openly even if they are not visible at all times. ${ }^{228}$ On the one hand, this expresses the common-sense intuition that not all weapons must be

219. See Lieber Code, supra note 27, art. 20.

220. See generally JAMES Q. WHITMAN, THE VERDICT OF BATTLE (2012) (charting the historical development of the idea of warfare as contest of violence, the outcome of which is binding on the parties to the conflict).

221. See Third Geneva Convention, supra note 25, art. 4(A)(2)(c); Huntley \& Levitz, supra note 217 , at 485 .

222. See DINSTEIN, supra note 27 , at 35.

223. See ICRC, COMMENTARY TO THIRD GENEVA CONVENTION, supra note 43, at 61 .

224. See Hague Convention of 1899 , supra note 39 , art. 1.

225. See ICRC, COMMENTARY TO THIRD GENEVA CONVENTION, supra note 43, at 61 .

226. See DINSTEIN, supra note 27 , at 45 (discussing whether the open arms requirement implies "that a combatant is barred from carrying a sidearm in a holster or hand grenades in a pouch"- -a question that the author concludes "is plainly rhetorical"); SolIS, supra note 5, at 196.

227. See ICRC, COMMENTARY TO THIRD GENEVA CONVENTION, supra note 43, at 61 .

228. Id. 
visible at all times, a requirement that does not accord with state practice. ${ }^{229}$ Clearly, it is permissible to pack up weapons to transport them from one location to the next - a common event for any military engagement. On the other hand, concealing weapons while walking into an engagement, for the purposes of feigning civilian status, is clearly prohibited. Pictet correctly observes that carrying arms openly is not just a physical description but rather is tied to deeper prohibitions against perfidy and general requirements of attribution, though the implications of this point are not explored. ${ }^{230}$

Fritz Kalshoven agrees that carrying arms openly meant something more than carrying arms "visibly."231 In particular, Kalshoven concludes that weapons need not be visible when out of sight of the enemy. ${ }^{232}$ In other words, the relevant arms need only be visible when the soldiers are within eyesight of the enemy; there is no requirement that arms should be visible when the soldiers are asleep in their barracks away from the front lines-an absurdly strict interpretation. ${ }^{233}$ In his commentary, Bothe correctly notes that the drafters of the Additional Protocols disagreed over how to interpret this requirement. ${ }^{234}$ On one view, arms should be visible only to the naked eye, while on the opposing view arms should be visible at night (due to infrared equipment) or even at a far distance (due to binoculars). ${ }^{235}$ The latter view, taken to its logical extreme, would suggest that arms should be visible at all times since modern armies can deploy spy airplanes and satellites to detect the enemy twenty-four hours a day regardless of location. Given the technological advance of artificially enhanced visual detection, the visibility requirement would now appear to be universal if one accepts this as a correct definition of the open arms requirement.

All of these discussions miss the deeper and more important sense in which the carrying of arms must be open. The requirement is closely connected to the prohibition against perfidy, a foundational element of the chivalric code of honor. ${ }^{236}$ It demands that a soldier stand up and perform the act of killing without hiding or deception, thereby taking responsibility for his or her actions.

229. See SolIS, supra note 5, at 196 (citing Additional Protocol I, supra note 62, art. 44(3) (" $[\mathrm{H}] \mathrm{e}$ shall retain his status as a combatant, provided that, in such situations, he carries his arms openly: (a) During each military engagement, and (b) During such time as he is visible to the adversary while he is engaged in a military deployment preceding the launching of an attack in which he is to participate.")) (concluding that the weapon must be visible at times when the combatant is visible to the enemy).

230. See ICRC, COMMENTARY TO THIRD GENEVA CONVENTION, supra note 43, at 61 .

231. See FrITS KALShoven, The Position of Guerilla Fighters Under the Law of War, in REFLECTIONS ON THE LAW OF WAR 467, 486 (2007).

232. Id. at 486-87.

233. See, e.g., Additional Protocol I, supra note 62, art. 44(3) (linking the requirement to moments when a combatant is "visible to the adversary while he is engaged in a military deployment preceding the launching of an attack in which he is to participate"); DINSTEIN, supra note 27, at 43; SOLIS, supra note 5 , at 196.

234. See Michael Bothe ET AL., New RULES for Victims of ARMED CONFLiCtS: Commentary on the Two 1977 Protocols additional to the Geneva Conventions of 1949 287 (2d ed. 2013).

235. Id. at 289.

236. Cf. Terty Gill, Chivalry: A Principle of the Law of Armed Conflict?, in ARMED CONFLICT AND INTERNATIONAL LAW: IN SEARCH OF THE HUMAN FACE 33, 37 (Mariëlle Matthee et al. eds., 2013) (discussing historical development of chivalry as a professional and legal norm). 
The prohibition on perfidy is not just limited to feigning civilian status in order to draw the enemy closer-a tactic that is not only unfair but also unduly risks future civilians who may be harmed because a soldier is unsure if he faces a bona fide civilian or a threatening solider hiding in civilian dress. ${ }^{237}$ The prohibition runs far deeper and is connected to the foundational notion that individual soldiers fight and kill on behalf of the collective that they represent; the nation advances and retrogrades with the soldier on the field and the soldier embodies the civilians at home whose lives will be impacted by the results on the battlefield. ${ }^{238}$

Recent military engagements in Ukraine are illustrative of this phenomenon. As Russian and Ukrainian officials negotiated over the political status of the Crimean peninsula, which is formally part of Ukrainian sovereign territory, military vehicles and personnel began showing up in key political and strategic sites across Crimea. ${ }^{239}$ They would not identify themselves to reporters or local civilians, and the Russian government said nothing about these deployments. ${ }^{240}$ Although the soldiers wore uniforms that were unmistakably military in nature, the clothing was stripped of all identifying insignia that established their link to a particular nation-state or government. ${ }^{241}$ Although it was widely assumed that these forces were operating at the direction of the Kremlin, this conclusion was initially mere supposition. ${ }^{242}$ Eventually, Ukrainian forces departed from the Crimean peninsula and ceded the territory to Russian control. ${ }^{243}$ Western political leaders criticized the development as an illegal annexation under the threat of military force. ${ }^{244}$

237. DNSTEIN, supra note 27 , at 35 ("Blurring the lines of division between combatants and civilians is bound to end in civilians suffering the consequences of being suspected as covert combatants.").

238. This is an ancient notion. See M.H. KeEN, THE LAws of WAR IN THE LATE MIDDLE AgES 106 (1965) ("[T]he usual sign of such war was the display of the banner of the prince in whose name it was fought. Once his banner was unfurled, he had given a challenge to combat and a state of war legally existed. From this moment on, the laws of war were in force.").

239. See Andrew Higgins, Amid More Signs of Russian Force in Crimea, Delight Mixes With Dismay, N.Y. TIMES, Mar. 1, 2014, http://www.nytimes.com/2014/03/02/world/europe/tensions-rise-in -crimean-capital-as-armed-men-continue-to-take-up-posts.html ('None of the heavily armed soldiers had insignia on their green combat uniforms, and for days, Russia insisted that it was just a spectator to the dramatic events unfolding in the Ukrainian region of Crimea and was as puzzled as everyone else by the identities of masked gunmen who had seized Crimea's two main airports and its Parliament and main government office buildings.").

240. Id.

241. See Mitch Potter, Ukraine Crisis: Russia's Gloves Come Off as the Insignia Go On, TORONTO STAR, Mar. 1, 2014, http://www.thestar.com/news/world/2014/03/01/ukraine_crisis_russias gloves_come_off_as_the_insignia_go_on.html.

242. The implications of using troops without insignia is analyzed in Jens David Ohlin, Crisis in Crimea: Can Putin Claim Consent?, VerdICT (Mar. 8, 2014), http://verdict.justia.com/2014/03 108/crisis-crimea-can-putin-claim-consent.

243. See Mark Memmott, Ukrainian Troops' Departure From Crimea Isn't a Simple Matter, NPR (Mar. 20, 2014, 7:30 AM), http://www.npr.org/blogs/thetwo-way/2014/03/20/291757956/ukrainian -troops-departure-from-crimea-isnt-a-simple-matter.

244. The concession was also accompanied by a referendum in which the local population, most of whom were ethnic Russians, voted overwhelmingly in favor of leaving Ukraine and joining Russia. David M. Herszenhorn, Crimea Votes to Secede From Ukraine as Russian Troops Keep Watch, N.Y. TIMES, Mar. 16, 2014, http://www.nytimes.com/2014/03/17/world/europe/crimea-ukraine -secession-vote-referendum.html. 
The presence of military personnel of uncertain provenance in Ukrainian territory was deeply distressing. ${ }^{245}$ Although the soldiers carried arms "openly" in the sense that their rifles were visible for all to see, there was an important sense in which the military deployment was not "open" at all. ${ }^{246}$ The military forces and the Russian government wanted to obscure the relationship between the forces and the political leaders who had ordered them there; perhaps they did so in order to be able to enjoy plausible deniability if the military and political situation soured quickly. Perhaps they wanted to preserve the option of arguing that the soldiers were, in fact, local militias organized by proRussian residents of the Crimean region agitating for secession. Although this was clearly not the case, the existence of a local, homegrown militia would have been more favorable to Russia's political and legal argument that Crimea should be allowed to secede from Ukraine. ${ }^{247}$

The common-sense intuition that the Russian deployment was not "open" is correct, though the standard commentaries fail to discuss the more complex ways in which the deployment of military force is not open. In this case, the arms were not carried openly because Russia was not making its involvement clear. It was trying to obscure - in fact hide - that it was using military force on foreign territory. And it was doing so not merely by traveling under cover of darkness or operating with camouflage (two time-honored and lawful techniques) but rather by removing the insignia that identified the troops as belonging to the Russian Army. By doing so, it created a situation in which Russia was not carrying arms openly in the collective sense.

In order to complete this argument, it is important to understand two little-understood elements of the architecture of the laws of war. First, the principle of distinction is specific, not general: the duty to distinguish includes not only the duty to separate soldiers from civilians but also the duty to separate friendly from enemy soldiers, a process that implicitly requires acknowledgement that force has been deployed. ${ }^{248}$ Second, the privilege of combatancy is collective, not individual. It is based on criteria that can only be fulfilled by the entire fighting force, not any single individual. ${ }^{249}$ Consequently, the privilege can only be asserted by a collective on behalf of individuals-an operation

245. But see Ewen Macaskill, Russian Troops Removing ID Markings "Gross Violation," THE GUARDIAN: DEFENCE \& SECURITY BLOG (Mar. 6, 2014, 10:56 PM), http://www.theguardian.com/news /defence-and-security-blog/2014/mar/06/ukraine-gross-violation-russian-troops (explaining that IHL experts criticize lack of insignia on troops, but ICRC officials claim that it is unclear whether this is a violation of the Geneva Convention, saying, "we focus on humanitarian need, not to criticise or judge, not to say who is right or wrong. There are different parties. We are very sensitive to this.").

246. See Ohlin, supra note 242.

247. In contrast to the quick developments in Crimea, the armed conflict in Eastern Ukraine in 2014 developed slowly enough for local separatists to organize their own militia, albeit with covert logistical support and arms from Russia. See Interview by Bob Schieffer with John Kerry, Sec'y of State, U.S. Dep't of State (July 20, 2014), http://www.state.gov/secretary/remarks/2014/07/229509.htm ("And we know that the Russians have armed the separatists, trained the separatists, support the separatists, and have to date, not publicly called on the separatists to stand down or to be part of this solution.").

248. See infra Section V.B.

249. See KALSHOVEN, supra note 231, at 487 (discussing the judicial determination that the Front for the Liberation of Palestine collectively fails to carry arms openly, regardless of what any single individual does). 
which is logically impaired by the state's refusal to acknowledge ownership of the troops. Covert action and unacknowledged uses of force make it impossible for the state to assert the privilege on one hand and then deny the existence of the troops at the very same time. ${ }^{250}$ Each of these issues will now be addressed.

\section{B. The Principle of Distinction is Specific, Not General}

The twin requirements of carrying arms openly and wearing a fixed emblem both flow from the more general principle of distinction in the law of war. ${ }^{251}$ The standard view is that the principle of distinction is designed to separate, in the view of the enemy, combatants from civilians. ${ }^{252}$ Under this view, the law of war is based on a basic gambit: soldiers are required to limit their attacks to combatants and never kill civilians unless as collateral damage. Consequently, soldiers are required to facilitate this requirement by distinguishing themselves from protected civilians. ${ }^{253}$ The prohibition on perfidy also codifies the prohibition on appearing as a civilian while engaging in acts of belligerency. ${ }^{254}$ The law's treatment of spies and saboteurs behind enemy lines (as criminals not entitled to the privilege) reflects the same intuition. ${ }^{255}$ Indeed, these elements are intertwined as predicate elements of the general principle of distinction; the law of war simply would not work if attacking forces were required to limit their attacks to soldiers but enemy soldiers were not required to distinguish themselves from the civilian population. The resulting chaos, which one typically finds in military engagements against partisans and terrorists, would be the norm for all warfare. . $^{256}$

This view of the scope of distinction is overly narrow. The duty to distinguish oneself is tied both to the requirements of wearing a fixed emblem and carrying arms openly and is not limited to distinguishing oneself from civilians. When viewed along with the prohibition against perfidy, it includes a more tion V.C.

250. One way of understanding this point is to view it as a principle of estoppel. See infra Sec-

251. See ICRC, COMMENTARY TO THIRD GENEVA CONVENTION, supra note 43, at 61 (explaining that the rule is designed to preserve loyalty in fighting). For a discussion of this point, see LINDSEY Cameron \& Vincent Chetail, PRIVATIZING WaR: PrIVATE Military and SeCurity Companies UNDER PUBLIC INTERNATIONAL LAW 404 (2013) (linking insignia and carrying-arms-openly requirements with principle of distinction); DINSTEN, supra note 27 , at 43 .

252. ICRC, CUSTOMARY IHL RULES, supra note 8, at 3 ("Rule 1. The parties to the conflict must at all times distinguish between civilians and combatants.").

253. Id. at 384 (Rule 106).

254. For a discussion of the scope of the prohibition on perfidy, see John Dehn, Permissible Perfidy?: Analysing the Colombian Hostage Rescue, the Capture of Rebel Leaders and the World's Reaction, 6 J. INT'L CRIM. JUST. 627, 631-33 (2008) (discussing the origins of the prohibition against perfidy); see also Lieber Code, supra note 27, art. 101 ("While deception in war is admitted as a just and necessary means of hostility, and is consistent with honorable warfare, the common law of war allows even capital punishment for clandestine or treacherous attempts to injure an enemy, because they are so dangerous, and it is difficult to guard against them.").

255. See infra notes $262,267$.

256. The frequency of terrorist attacks and military action against non-state actors may already be pushing in that direction. For a discussion of the breakdown of traditional notions of reciprocity, see generally MARK OSIEL, THE END OF RECIPROCITY: TERROR, TORTURE, AND THE LAW OF WAR (2009) (criticizing well-established justifications for reciprocity, and arguing that each fails to support a policy of restraint in fighting al-Qaeda or similar non-state actors). 
general duty to make explicit on the battlefield the particular link between the individual soldier and the collective on whose behalf he or she operates. ${ }^{257} \mathrm{In}$ other words, the duty to distinguish oneself--both from civilians and from other parties to the armed conflict-is not just an end to itself but is, rather, an instrumental imperative upon which the entire machinery of jus in bello rests. In the absence of proper attribution, none of the rules of jus in bello operates smoothly. The most obvious example is that distinction is necessary for attribution of liability for war crimes, but in fact the instrumental reasons sweep much broader and deeper.

More specifically, distinction is important for tactical, moral, political, and diplomatic reasons. The tactical reason is that a soldier, when faced with an unfamiliar soldier, must quickly assess whether he is an enemy soldier, a soldier from his own military force, or a soldier from a friendly co-belligerent force. ${ }^{258}$ This is a far more complex assessment than simply determining combatant versus civilian status and will help determine whether or not the soldier will engage the approaching individual. In other words, the assessment of the approaching individual as friendly or not requires identifying the particular fighting force one is confronting on the battlefield. Indeed, this view is clearly implicit in the prohibition on perfidy. A soldier is guilty of perfidious conduct if he infiltrates an enemy position while wearing the uniform of his enemy in order to launch a surprise attack. ${ }^{259}$

The standard texts do not always recognize this broad understanding of distinction and it is common to hear scholars express a narrower version. For example, Dinstein correctly notes that having a fixed emblem "is predicated on the two-pronged requirement of distinctiveness (viz. it must identify and characterize the armed force using it)," though he then goes on to conclude that wearing a standard uniform "with all proper insignia . . . is not strictly necessary" without apparent awareness of the tension between these two statements. ${ }^{260} \mathrm{He}$ then notes, as others frequently do, that special forces often wear non-standard uniforms, a process that he finds "unobjectionable" as long as the combatants are distinguishable from civilians. ${ }^{261}$ Parks holds a similar view, arguing that a non-standard uniform for special forces is permissible. ${ }^{262}$ Alt-

257. Provost concludes that the normative basis for protection by the principle of distinction and other humanitarian principles is membership in a group. See RENÉ Provost, INTERNATIONAL HUMAN RIGHTS AND HUMANITARIAN LAW 42 (2004).

258. For a discussion of perfidy, see Yves Sandoz, Land Warfare, in THE OXFORD HANDBOOK OF INTERNATIONAL LAW IN ARMED CONFLICT 91, 98 (Andrew Clapham \& Paola Gaeta eds., 2014).

259. See ICRC, CUSTOMARY IHL RulES, supra note 8, at 213 ("Rule 62. Improper use of the flags or military emblems, insignia or uniforms of the adversary is prohibited."). The ICRC study describes this as a rule of IHL but also notes that "[i]t can be argued that it should also apply in noninternational armed conflicts when the parties to the conflict do in fact wear uniforms." $I d$. at 214 .

260. DINSTEIN, supra note 27 , at 43 .

261. Id.

262. See W. Hays Parks, Special Forces' Wear of Non-Standard Uniforms, 4 CHI. J. INT'L L. 493, 525 (2003) (arguing that state practice supports deployment of special forces in civilian attire or non-standard uniforms). Indeed, Parks concludes that "state practice reflects an overt tolerance bordering on admiration for special forces wearing civilian clothing when working with indigenous persons in enemy-denied areas, whether for intelligence gathering or combat operations." Id. However, Parks also concedes that special forces wearing civilian attire have traditionally been treated as spies upon capture. Id. This implies by logical deduction that they are unprivileged combatants. 
hough plenty of texts view distinction as merely a question of combatants versus civilians, its underlying rationale requires that soldiers identify themselves as belonging to a particular political entity on whose behalf they fight. ${ }^{263}$ Nothing short of this level of identification will provide an enemy soldier with sufficient information to determine whether the approaching individual is friend or foe, whether the approaching individual should be shot or welcomed.

Indeed, the entire concept of distinction is collective, and specific to a particular force on whose behalf the individual fights, because there is no such thing as being a combatant in abstracto. The narrow view of distinction fails to recognize this reality. Combatants are always fighting with a particular group, and the law of war ties the requirements of lawful belligerency to elements that can only be satisfied by a group (command structure, the group's obeying the customs of war, etc.). ${ }^{264}$ To be a lawful combatant is to be fighting with, and on behalf of other individuals, brought together in the right way and recognized by the law of war as a fighting organization. This is precisely why the duty to wear a fixed emblem and carry arms openly, and the associated prohibition on perfi$\mathrm{dy}$, all require soldiers to be positively linked to a particular fighting force.

Applying this insight to the use of covert action, it becomes clear why an unacknowledged use of force is so problematic. The issue is more than just uniforms, emblems, and insignias. The cluster of IHL requirements discussed above requires a conceptual and political link between the soldier and a collective force, but covert and unacknowledged uses of force seek to evade-or in fact explicitly deny-that connection. ${ }^{265}$ This produces more than just a tension-it produces a downright contradiction. In order to be identified with a particular fighting force and meet the requirements of carrying arms openly, the soldier must be identified as fighting on behalf of a collective, a link that is explicitly denied in covert action. ${ }^{266}$ The result is a logical contradiction. The best resolution of this paradox is to concede that soldiers engaged in covert action do not meet the standards for carrying their arms openly because the operative link to state responsibility is negated by the covert nature of the action. Although this conclusion may seem surprising and counterintuitive, the basic structure of the argument is sound. Soldiers engaged in covert action do not meet the basic standards for lawful belligerency and therefore are not entitled to the privilege of combatancy. If captured in enemy territory they may be prosecuted for violations of domestic criminal law. Furthermore, the fact that the soldiers in question are wearing military uniforms, or even belong to the uniformed Armed Services, does not change this result. ${ }^{267}$ Even uniformed mili-

263. See DINSTEIN, supra note 27 , at 43 . Dinstein also concludes that all military vehicles must be properly identified. See id. at 45 .

264. See KALSHOVEN, supra note 231 , at 487.

265. But see Huntley \& Levitz, supra note 217 , at $485-86$ (arguing for broad application of the combatant's privilege for "surrogate" armed forces).

266. Id . at 492 (noting that "the most serious jus in bello challenge in clandestine and UW [unconventional warfare] operations (and one that would somewhat limit surrogate activities) is the principle of distinction").

267. It is important to remember that the functional requirements of belligerency apply, by custom, to the regular armed forces. See ICRC, CUSTOMARY IHL RULES, supra note 8, at 385 ("Several military manuals remark that the obligation to distinguish oneself does not pose a problem for the regu- 
tary forces, such as Navy SEALs, do not have the privilege of combatancy when engaged in covert action under Title 50 , simply because the required link between the soldier and the fighting force is negated by the covert status of the engagement. $^{268}$

\section{The Privilege is Collective, Not Individual}

The final piece of the argument involves the collective nature of the privilege of combatancy. The standard assumption is that the privilege belongs to the individual combatant. The privilege operates as an immunity that transforms what would otherwise be an unlawful act of murder into a lawful act of belligerency, by virtue of the fact that the soldier is a legitimate belligerent. ${ }^{269}$ In other words, the privilege is a legal trump that blocks foreign powers from prosecuting an individual soldier for acts of lawful belligerency during armed conflict. ${ }^{270}$ Like other legal trumps that protect individuals from government action, it is tempting to conceptualize the privilege as an individual right against collective action on behalf of a state. ${ }^{27}$

While tempting, this approach is misleading and incorrect. The privilege is collective in nature because it belongs primarily to the fighting force engaged in the armed conflict. There are several reasons for this conclusion. First, the privilege only applies if there is an armed conflict, which by definition involves a contest between organized armed groups that constitute the parties to the armed conflict. ${ }^{272}$ Without the parties there is no armed conflict; without an armed conflict there is no privilege of belligerency. Second, the criteria for POW status and the associated privilege are all group criteria: the group must wear a fixed emblem, carry arms openly, and comply with the laws of war. ${ }^{273}$

lar armed forces because it is 'customary' or 'usual' for members of the regular armed forces to wear a uniform as a distinctive sign. If members of regular armed forces do not wear a uniform, they risk being charged as spies or saboteurs."). For a full defense of this conclusion, see supra Section I.B.

268. See Alston, supra note 212, at 369-70 (describing lack of privilege in most covert actions). It should be noted that the unprivileged nature of the deployment does not, by itself, entail that the use of force is unlawful from the perspective of jus ad bellum. See Marty Lederman, Unprivileged Does Not Mean Prohibited, JUST SECURITY (Sept. 26, 2013, 2:05 PM), http://justsecurity.org/1153 /unprivilegedunlawful (concluding that unprivileged belligerents violate domestic criminal law).

269. See Miriam J. Aukerman, War, Crime, or War Crime? Interrogating the Analogy Between War and Terror, in ENEMY COMBATANTS, TERRORISM, AND ARMED CONFLICT LAW 145, 147 (David $\mathrm{K}$. Linnan ed., 2008) (describing membership in a fighting collective as a necessary condition for applying the privilege).

270. See RONALD DWORKIn, TAKING RIGHTS SERIOUSLY 188-97 (1977) (defining a political right as a trump against public welfare arguments or general utilitarian justifications).

271. Id.

272. The modern definition of armed conflict was articulated by the ICTY Appeals Chamber in Prosecutor v. Tadic, Case No. IT-94-1-A, Decision on the Defence Motion for Interlocutory Appeal on Jurisdiction, I 70 (Int'l Crim. Trib. for the Former Yugoslavia Oct. 2, 1995), which defines armed conflict as "protracted armed violence between governmental authorities and organized armed groups or between such groups within a state." For a discussion, see CULLEN, supra note 31, at 27; SIVAKUMARAN, supra note 13, at 170 (discussing organizational requirements for armed conflict); Steven Haines, The Nature of War and the Character of Contemporary Armed Conflict, in INTERNATIONAL LAW AND THE ClASSIFICATION OF CONFLICTS 9, 10 (Elizabeth Wilmshurst ed., 2012); and How is the Term "Armed Conflict" Defined in International Humanitarian Law?, INT'L COMM. OF THE RED CROSS (Mar. 2008), http://www.icrc.org/eng/assets/files/other/opinion-paper-armed-conflict.pdf.

273. See supra Section I.A. 
Consider a single individual who complies with these requirements but fights for an organization that fails to meet them. The individual fights for a terrorist organization but the single individual decides to wear a uniform, carries his arms openly, and limits his attacks to enemy soldiers and refuses to target innocent civilians. ${ }^{274}$ As much as this individual is commendable, he would not be eligible for POW status or the associated privilege, since the group to which he belongs does not meet the standard. ${ }^{275}$ And with good reason: if the group in general does not meet the requirements, then the other party to the armed conflict cannot conduct its military operations with the security of knowing that its counterparts are complying with the basic structure of the law of war. Rather, they would need to proceed with the knowledge that most of the enemy is mixing with the civilian population and not carrying arms openly. The fact that one individual soldier (or even several soldiers) is complying with the rules is not enough to change the situation. Third, the collective nature of the privilege is confirmed by the bare text of the Third Geneva Convention, which requires belligerents to be afforded POW status when "militias or volunteer corps, including such organized resistance movements, fulfill [certain] conditions.,"276 In other words, one looks to the group's compliance with the functional criteria to determine if its members are entitled to the privilege. ${ }^{277}$

Finally, the privilege of combatancy is an implicit obligation between parties to the armed conflict that they will respect offers of surrender, grant POW status, and defer prosecution of enemy soldiers for lawful acts of belligerency. ${ }^{278}$ These obligations run between the collectives themselves, not from the collective to the soldier himself. ${ }^{279}$ At most, the individual soldier is a thirdparty beneficiary whose welfare is very much at stake in the performance or non-performance of these obligations. ${ }^{280}$ If a state violates its obligations and mistreats or prosecutes an enemy soldier, then we conclude that the soldier's state has been victimized by an internationally wrongful act. The collective analysis goes further. It is impossible to understand the combatant's privilege unless the collective asserts it on behalf of the individual. The collective must assert that the individual is fighting on its behalf and deserves the treatment required by the law of war, but only after the collective recognizes the existence of an armed conflict with soldiers fighting on behalf of two collectives. ${ }^{281}$

This explains why covert action is incompatible with the combatant's

274. See, e.g., Status of Taliban Forces Under Article 4 of the Third Geneva Convention of 1949, Op. Off. Legal Counsel, 2002 WL 34462404 (Feb. 7, 2002) (engaging in collective analysis though controversially concluding that President alone can make determination).

275. See United States v. Lindh, 212 F. Supp. 2d 541, 557-58 (E.D. Va. 2002) (analyzing organizational criteria to determine petitioner's claim to POW status).

276. See Third Geneva Convention, supra note 25, art. 4(2).

277. This requires a difficult practice of line drawing if the group is a mixture of compliant and non-compliant forces. What percentage of compliance is required to meet the Article 4 standard? There are no easy and non-arbitrary answers to this question, but in any event this problem is unavoidable and should not be counted as a deficit of the theory presented in this Article.

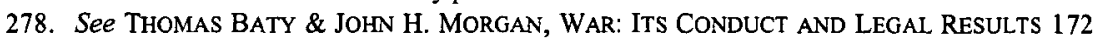
(1915) (explaining the collective nature of conflict).

279. Id.

280. See Provost, supra note 257 , at 42.

281. Cf. Dormann, supra note 5, at 268-69. 
privilege. Since a state must acknowledge the existence of the armed conflict and the soldiers fighting on its behalf, the existence of the covert action becomes a logical bar to the invocation of the privilege. ${ }^{282}$ One way of explaining the point is to think of it as a form of estoppel. ${ }^{283}$ A state cannot refuse to acknowledge the use of force and then claim that the soldiers who fought in the military engagement are entitled to the privilege. ${ }^{284}$ Once the state denies that the military action was taken on its behalf, it is then estopped from claiming that the soldiers are part of a privileged fighting force. ${ }^{285}$ Or, put the opposite way, once the state asserts the privilege on behalf of its forces, it is estopped from denying responsibility for the military incursion. ${ }^{286}$ It must stand up and carry its arms openly. The structure of the privilege is similar to diplomatic immunity, which must be asserted by a state on behalf of the individual, and in theory can be waived by the state if so desired (even to the detriment of the individual criminal defendant). ${ }^{287}$ Furthermore, any violation of diplomatic immunity is a matter of international concern to be resolved by the states involved. $^{288}$

All three arguments presented in this Part must be viewed together because they form an interrelated cluster of obligations. Military forces must wear a distinctive emblem and carry their arms openly because the principle of distinction requires the identification of combatants with a particular fighting force; the collective itself asserts the privilege and can only do so when it acknowledges that the troops were operating on its behalf. When applied to the deployment of drones in a conflict with a non-state actor, it becomes clear that

282. Indeed, the Department of Defense does not officially acknowledge that JSOC commands various special mission units or that its primary mission is "identifying and destroying terrorist and terror cells worldwide." ANDREW FEICKERT, CONG. RESEARCH SERV., RS21048 U.S. SPECIAL OPERATIONS FORCES (SOF): BACKGROUND AND ISSUES FOR CONGRESS 5 (2013), http://www.au.af.mil /au/awc/awcgate/crs/rs21048.pdf.

283. See Richard H. Field et al., Civil Procedure: Materials for a Basic Course 705 ( 1 th ed. 2014) (discussing equitable principle of estoppel); see generally HENRY MORRISON HERMAN, THE LAW OF ESTOPPEL (Albany, W.C. Little \& Co. 1871) (cataloguing a variety of estoppel arguments in the common law).

284. The principle of estoppel unquestionably applies in international law. See ANTHONY AUST, HANDBOOK ON INTERNATIONAL LAW 8 (2d ed. 2010). But see BROWNLIE, supra note 77, at 644 (recognizing that the principle of estoppel is undeniably a part of international law but also complaining that "the 'principle" has no particular coherence in international law, its incidence and effects not being uniform").

285. For applications of estoppel in the context of armed conflict, consider the arguments raised by al-Nashiri's counsel in federal court that the U.S. government was precluded from asserting the existence of an armed conflict with al-Qaeda in 2000 because President Clinton stated publicly that the country was not at war. See Memorandum of Law in Support of Petitioner's Motion for Preliminary Injunction at 18, Al-Nashiri v. Obama, No. 08-CIV-1207 (D.D.C. Apr. 21, 2014); see also ChRISTOPHER H. Pyle \& Richard M. Pious, The Constitution Under Siege: Presidential Power versus the RULE OF LAW 230 (2010).

286. The principle of estoppel is frequently applied in international litigation. See, e.g., Temple of Preah Vihear (Cambodia v. Thai.), 1962 I.C.J. 6, 32 (June 15) (concluding that Thailand was estopped by conduct from claiming invalidity of treaty); Military and Paramilitary Activities in and against Nicaragua (Nicar. v. U.S.), 1984 I.C.J. 392, $412-13$ (Nov. 26) (showing acceptance of court's jurisdiction via estoppel).

287. See generally EILEEN DENZA, DiPlomatic LAW: COMMENTARY ON THE VIENNA CONVENTION ON DiPLOMATIC RELATIONS (3d ed. 2008) (surveying the privileges and immunities of diplomatic officers).

288. Id. 
drone operators do not enjoy the privilege of combatancy when the force is covert and unacknowledged. Despite popular belief, this conclusion has little to do with whether the operators are CIA employees or uniformed members of the armed services. ${ }^{289}$ Even uniformed members of the military are not entitled to the privilege if the United States is acting covertly and refuses to acknowledge an operative link to the soldiers. ${ }^{290}$ Whatever the reasons for moving control over drone deployment from the CIA to the Department of Defense, the privilege of combatancy is not one of them, as long as the strikes are conducted in a covert posture.

The loss of the combatant's privilege for drone operators, including uniformed members of the Armed Services, may not be particularly disturbing for the U.S. government. ${ }^{291}$ In many cases the reason for the covert nature of the deployment may be that the United States is operating with the consent of the local government but that consent is predicated on U.S. non-acknowledgment of military participation in the local theater of war. ${ }^{292}$ In that case it is unlikely that the local government would prosecute U.S. service members even in the absence of the combatant's privilege. ${ }^{293}$ The agreement or understanding between the states may even include a promise that the host state will not prosecute American service members under its domestic law. Even in the absence of an explicit agreement, the prosecution of an American service member would reveal the very foreign assistance that the host state is hoping to conceal, thus making a prosecution counterproductive and unlikely.

However, there are still reasons to care about the loss of the combatant's privilege. First, it reveals that the decision to place control over paramilitary operations in CIA or Defense Department control should be made on the basis of other legal and policy considerations, not the combatant's privilege. Second, if the local government is overthrown by the rebels, or even changes administrations, the new government may not honor the original agreement, thus making the privilege pertinent again. Third, individual combatants might care whether they carry the combatant's privilege-a fact that may alter their psychological attitude regarding their conduct. ${ }^{294}$ Finally, the basic structure and scope of the privilege is central to the conceptual architecture of the law of war and ought to be properly understood, independent of its consequences for any particular strategic debate.

289. See Burt \& Wagner, supra note 208 , at 11.

290. See supra notes 252-268 and accompanying text.

291. For a discussion of the U.S. government position, and a critique of it, see Scott Horton, The Trouble with Drones, HARPER's MAG.: BRowsINGS (May 3, 2010, 12:37 PM), $\mathrm{http} / /$ harpers.org/blog/2010/05/the-trouble-with-drones (noting that the real problem with using unprivileged drone operators is U.S. hypocrisy).

292. See Lederman, supra note 194 (discussing reasons for non-acknowledgment).

293. Some of these factors are discussed in MAZZETTI, supra note 196, at 196.

294. See also Mégret, supra note 74, at 529 (discussing psychological elements of combatant's privilege in the NIAC context). 


\section{Retroactive Acknowledgment}

Prior Sections highlighted, but did not resolve, the problems posed by retroactive acknowledgment. In some cases a state may deploy force that is covert and unacknowledged at the time the force is deployed, but then at a later point in time the state might officially acknowledge the force. In particular, this procedure might be attractive to a state that is unsure of how the deployment will unfold, both in terms of strategic outcomes and the degree of IHL violations that occur during the deployment. If the operation goes poorly, the state might continue to disavow any knowledge of the operation. On the other hand, if the operation is a strategic success (and if collateral damage is minimized), the state may wish to acknowledge the deployment after the fact. The acknowledgment might come years later or it might come in a matter of hours or days. The Navy SEAL raid on Osama Bin Laden's compound is just one example. Had the raid gone poorly, it is entirely conceivable that the United States might have denied involvement. As it happens, the raid was a success and government officials were happy to take credit for the operation.

There is a further complication here that becomes apparent only when the temporal issue is analyzed. What is the definition of "unacknowledged," and does governmental silence always qualify as a denial of involvement? In other words, a government may refuse to confirm or deny that the operation was state sanctioned. In that case it seems clear that it is unacknowledged, but what if no one asks the state about the deployment because its existence was completely — or mostly - a well-kept secret? If no one asks, the government's silence could be construed as evidence of non-acknowledgment or simply as evidence of the operation's clandestine (i.e., secret) nature. In some cases, the state's internal legal structure, such as Title 10 or Title 50 of the U.S. Code, may provide a reasonable proxy for whether the government is willing to acknowledge the force if asked for more information about the operation. Unfortunately, not every state has segregated legal mechanisms for acknowledged and unacknowledged legal mechanisms, and even in the United States, the operation's authorization under Title 10 and the auspices of the Department of Defense is no guarantee that the government will officially acknowledge its role in the military operation if and when it is asked.

One possible solution to the temporal problem is to insist that the state acknowledge the force at the time when the force is being deployed. This view solves the temporal problem and is best supported by the broad interpretation of the open arms requirement discussed above. If the state does not acknowledge the force when it is deployed, then the force is not "open." Indeed, retroactive acknowledgment fails to cure the violation of the open arms requirement, just as retroactive statements could not solve any other violation of the functional requirements of belligerency. This view is also supported by the needs of individual soldiers with regard to the principle of distinction. To the soldier in Eastern Ukraine or Crimea trying to figure out what to do, it matters little whether or not the Russian government retroactively acknowledges that the military troops that operated there, in the distant past, were deployed on Russia's behalf. Indeed, even a retroactive acknowledgment shortly after the de- 
ployment is irrelevant from the perspective of the individual soldier operating in that environment.

Unfortunately, none of this solves the conundrum involved in state silence after an operation that remains a well-kept secret. One plausible answer to this question is that it should be classified as clandestine force but not unacknowledged force. Acknowledgment or lack of acknowledgment presumes that the world knows about the military force and starts asking questions about who is behind it. If the force is truly secret, the issue of acknowledgement or lack of acknowledgment never arises. On the other hand, if the kinetic attack is known publicly, and the state is asked about the attack, and the state either denies its involvement or refuses to answer the question, then it constitutes unacknowledged force. Under this standard, the military campaigns by the Russians in Crimea, the Americans in Yemen, and the Americans in the tribal regions of Pakistan all qualify as unacknowledged force because when asked explicitly about state involvement, government officials either denied involvement or refused to answer the question.

This standard leaves unresolved the status of isolated and very brief operations that are "one-off' deployments that happen once and are not repeated. The standard expressed above does not address these limited scenarios. In these cases, the operation begins and ends before the public has a chance to ask the government about the operation. It is unclear whether or not these quick deployments should count as unacknowledged or not. But uncertainty about the application of the basic principles to that limited factual scenario should not cloud the certainty of our judgments in the more typical case: a lengthy military campaign with repeat deployments that remain unacknowledged by the government, during the course of the campaign, when asked about state involvement. This was certainly the case with regard to Putin's refusal to acknowledge operations in Crimea, and Obama's unwillingness to acknowledge operations in Yemen and Pakistan while those operations were ongoing. Questions were asked; answers were either not given (Obama) or were deceptive (Putin). In each case, the unacknowledged nature of the force prevented the military operatives from fulfilling the open arms requirement, and no amount of retroactive acknowledgment, years later, will cure this fact.

\section{E. Mixed Deployment of Complex Weapons Platforms}

The prior Sections of Part V argued that covert actions are-by definition-inconsistent with the underlying functional requirements for the privilege of belligerency. The argument had two crucial elements. First, a state cannot assert the privilege on behalf of its troops and at the same time deny that the troops acted on its behalf. Second, unacknowledged force violates the open arms requirement and frustrates the principle of distinction underlying it. This suggests that even uniformed military personnel engaged in covert action are not entitled to the privilege. However, we have yet to address an important factual complication: uniformed and non-uniformed personnel working in tandem jointly conduct some drone operations. In many cases, uniformed troops who usually operate under Title 10 are co-deployed with CIA personnel in a covert 
action that is best described either as a Title 50 action or a "hybrid" Title10/Title 50 action. ${ }^{295}$ How should such mixed operations be analyzed under the law of war?

Discussions regarding drone operations often assume that control over their deployment is an either/or option between the intelligence agencies and the Department of Defense. In truth, the reality is far more complicated. Published reports indicate that even in cases where the CIA is in control of drone deployment in a particular theater of war, uniformed Air Force personnel sometimes handle the actual piloting of the drones. So the reality is that a mix of intelligence and uniformed agents handle drone operations, and there is substantial reason to believe that such hybrid deployments will become more-rather than less - common as interagency cooperation and harmonization continue to develop. ${ }^{296}$ Legal discussion has lagged far behind these factual developments. Consequently, this Part will trace the legal consequences for the combatant's privilege in hybrid deployments of uniformed and non-uniformed intelligence personnel. ${ }^{297}$

In particular, it is unclear what it means to "carry arms openly" in situations where the weapons system is a complex platform with tens or even hundreds of individuals participating in its deployment. The standard textbook discussions of carrying arms openly deal with rifles, side-arms, and grenades, but little to no discussion of aircraft carriers, intercontinental ballistic missiles, or remotely piloted vehicles--weapons whose complexity dwarfs the previous generation of weapons like rifles and grenades. ${ }^{298}$ Also, the standard discussions are infantry-based with little to no attention to how the norm applies to combat scenarios in other branches of the armed services or other modes of combat.

At least part of the uncertainty regarding application of the open arms standard stems from the remoteness of drones, which can be deployed from great distances and out of the visual range of the enemy (unless the enemy has radar or satellites). ${ }^{299}$ Of course, this is not a new phenomenon; snipers have always operated at a distance, and although they put pressure on the chivalric culture of warfare, state practice permits them. ${ }^{300}$ In similar fashion, cruise missiles, artillery shells, and long-range bombers all involve action at a distance

295. One might describe hybrid Title 10 /Title 50 actions as an attempt by the executive branch to "pool" the legal authority that normally resides in the Department of Defense and the CIA. See Daphna Renan, Pooling Powers, 115 Colum. L. REV. 211, 228 (2015).

296. Chesney, supra note 15 , at 540.

297. But see BOOTHBY, supra note 150 , at 287 (discussing the legal issue for an unmanned aerial vehicle of whether the controller "has the required status for the activities he undertakes").

298. For a discussion of the complexity of deploying modern weapons (and platforms), see generally CHRIS C. DEMCHAK, MiLITARY ORGANIZATIONS, COMPLEX MACHINES: MODERNIZATION IN THE U.S. ARMED SERVICES (1991).

299. See generally Gabriella Blum \& Philip Heymann, Law and Policy of Targeted Killing, 1 HARV. NAT'L SECURITY J. 145 (2010) (discussing the policy implications of using remotely piloted vehicles to kill enemy combatants without substantial risk to attacking forces).

300. Francis Lieber viewed snipers behind enemy lines as arguably unprivileged, even if wearing a uniform. See Lieber Code, supra note 27, art. 84. For a discussion of Lieber's complex treatment of snipers, see Burrus M. Camahan, The Civil War Origins of the Modern Rules of War: Francis Lieber and Lincoln's General Order No. 100, 39 N. KEN. L. REV. 661, 675-76 (2012). 
deployed by teams of combatants. ${ }^{301}$ The particular issue for debate here is the involvement of both CIA and Defense Department personnel in the execution of a drone strike. How does one assess the legality of CIA involvement in a drone piloted by Air Force personnel? ${ }^{302}$ If Air Force personnel comply with the basic standards of belligerency while the CIA personnel do not, is the drone strike an example of privileged belligerency or not?

One possible resolution to the debate is to view CIA employees engaged in paramilitary operations, especially drone targeting and deployment, as auxiliary members of the armed forces in accordance with Article 43 of Additional Protocol $\mathrm{I}^{303}$ Although this is a promising argument, there are multiple obstacles here. ${ }^{304}$ First, it appears the United States has never openly identified the CIA as an incorporated paramilitary force in accordance with Article $43 .^{305}$ Second, Additional Protocol I applies in international conflicts, and it is unclear which conclusion should be drawn from the lack of a corresponding provision for non-intemational conflicts in Protocol II. This could mean that such incorporations are prohibited in non-international conflicts or that they are permitted. Third, the discussion of the provision at Geneva centered on military police and other units designed to provide "internal law-keeping," as opposed to covert paramilitary actors. ${ }^{306}$ In fact, the section title of the ICRC commentary lists paragraph 3 as "Incorporation of police forces," and its discussion concludes with the narrow suggestion that "uniformed units of law enforcement agencies can be members of the armed forces if the adverse Party has been notified of this, so that there is no confusion on its part." ${ }^{, 307}$ It is therefore plausible that members of the U.S. Armed Services military police are incorporated into the armed services because they follow the Department of Defense's unified chain of command. ${ }^{308}$ In contrast, CIA paramilitary forces operate outside of the armed forces chain of command, thereby complicating any attempt to classify them as auxiliary members of the armed forces. ${ }^{309}$

301. See, e.g., Brian A. Jackson et Al., EVAluating Novel Threats to the Homeland: UNMANNED AERIAL VEHICLES AND CRUISE MISSILES 45 (2008).

302. For a discussion of these reported collaborations, see Chris Woods, CIA's Pakistan Drone Strikes Carried Out by Regular US Air Force Personnel, GUARDIAN, Apr. 14, 2014, $\mathrm{http}: / /$ www.theguardian.com/world/2014/apr/14/cia-drones-pakistan-us-air-force-documentary (suggesting that Air Force personnel located in Nevada operate CIA drones in Pakistan).

303. See Additional Protocol I, supra note 62, art. 43(3) ("Whenever a Party to a conflict incorporates a paramilitary or armed law enforcement agency into its armed forces it shall so notify the other Parties to the conflict.").

304. The argument is discussed at length in Henderson, supra note 32, at 152 (asking whether the CIA could be considered an incorporated paramilitary adjunct to the regular armed forces).

305. C.f. id. (suggesting that no international rule prohibits govermments from deciding which force they use to fight local insurgents in a non-international conflict); see generally Kenneth Watkin, Warriors Without Rights? Combatants, Unprivileged Belligerents, and the Struggle Over Legitimacy 6566 (Harvard Univ. Program on Humanitarian Policy \& Conflict Research, Occasional Paper Series 2, 2005) (discussing overlap between military and security operations in non-intemational conflicts).

306. See COMmentary on the AdDitional Protocols of 8 JUNE 1977 to the Geneva CONVENTIONS OF 12 AUGUST 1949, at 517 (Yves Sandoz et al. eds., 1987).

307. Id. at 518.

308. See also ICRC, CUSTOMARY IHL RULES, supra note 8, at 16-17 (incorporating substantial state practice of police forces into armed forces).

309. See CIA Organization Chart, U.S. Cent. InTElligence Agency (2014), https://www.cia.gov/about-cia/leadership/cia_org_chart.pdf. 
Another possibility is that the privilege is personal to each individual involved in the drone strike, such that Defense Department employees are privileged, whereas CIA officers are not. While seemingly plausible, this conclusion is deeply problematic. In conducting their operations, the uniformed members of the army are required by customary law to carry their arms openly, ${ }^{310}$ but in this case the uniformed members are "co-carrying" the weapon with unprivileged belligerents who are not carrying arms openly. There is almost no discussion in the literature regarding the "co-deployment" of weapons; every textbook assumes that weapons are personally deployed-an antiquated and erroneous assumption. ${ }^{311}$ In today's technologically advanced battlefield, soldiers cooperate and carry weapons in common as a joint cooperative activity. $^{312}$

This suggests that the privilege should be assessed collectively among all members who cooperate in the joint deployment of the weapon; they are, in a sense, "co-carrying" the weapon together. There is little in the law of armed conflict literature on the nature of co-deployment, but the most plausible account of such co-deployment is that the members are engaged in a joint cooperative activity. ${ }^{313}$ As I have explained elsewhere, the sine qua non of a joint cooperative activity is a joint or shared intuition to carry out the act in question. ${ }^{314}$ A joint or shared intuition is created when multiple individuals each have an intention that the group carry out the action based on a plan. ${ }^{315}$ Inevitably these plans require what Bratman refers to as the "meshing of sub-plans," i.e., an appropriate division of labor and a decision procedure for resolving uncertainties or disagreements about how to proceed. ${ }^{316}$ The joint deployment of a complex weapons system meets these criteria. In that situation, CIA employees and Air Force personnel engage in the joint cooperative activity of launching a drone strike.

Under this view, there is at least a plausible argument that American service members are not "carrying their arms" openly because they are jointly deploying the drone with members of a covert paramilitary force who do not meet the standards for lawful belligerency ${ }^{317}$ In theory, it does not matter how many CIA officers are involved in the drone deployment, as long as there is a significant number of CIA employees engaged in the joint cooperative activity.

310. See supra Section I.B (explicitly defending this conclusion).

311. See, e.g., BOTHE ET AL., supra note 234, at 288-89.

312. The term "joint or shared cooperative activity" comes from Bratman's work. See MiCHAEL E. BRATMAN, Shared Cooperative Activity, in FACES OF INTENTION: SELECTED ESSAYS ON INTENTION AND AGENCY 93, 93-108 (1999).

313. Id. at 94 .

314. For an exploration of this issue as it pertains to international criminal law, see Jens David Ohlin, Joint Intentions to Commit International Crimes, 11 CHI. J. INT'L L. 693, 735 (2011) (applying joint or shared intentions as a framework for mode of liability for cooperative criminal actions).

315. BRATMAN, supra note 312 , at 61 (discussing the significance of plans in a rational agency).

316. Id. at 100 .

317. See Woods, supra note 302; see also Aaron M. Drake, Current U.S. Air Force Drone Operations and Their Conduct in Compliance with International Humanitarian Law-An Overview, 39 DENV. J. INT'L L. \& POL'Y 629, 633 (2011) (discussing questions raised by CIA involvement in Air Force drone deployments). 
At some point the number of CIA individuals might drop so low as to become de minimis, though that threshold is difficult to quantify. But the issue need not be resolved here; it is sufficient to note that broad CIA joint deployment of a drone with uniformed military officers is sufficiently covert to negate the privilege for all individuals involved in the deployment.

One crucial aspect is to correctly identify the scope of the drone "deployment" and the associated joint cooperative activity. ${ }^{318}$ The scope can be drawn too narrowly or too broadly. For example, defining the joint cooperative activity as "the strategy of defeating the enemy with military force" would clearly be too broad and would generate the fallacious conclusion that any CIA involvement during an armed conflict would destroy the privilege for the entirety of the conflict. On the other hand, it would be just as fallacious to suggest that the relevant joint cooperative activity is some time-sliced micro-event with CIA involvement, such that the drone is deployed solely by Air Force personnel as long as they press the button that launches the missile at the very end of the event. ${ }^{319}$ Clearly, "deploying" a drone is a much more extensive process than merely pressing the button that fires the missile. The truth lays somewhere in between. One should take guidance from the operational definition of deployment-encompassing the takeoff, flight, missile launch, and landing-in order to understand the correct scope of the joint cooperative activity. ${ }^{320}$ As long as CIA personnel are involved in this process, the co-deployment is not an example of carrying arms openly.

However, it would be wrong to assume that CIA participation in target selection and intelligence gathering more generally negates the privilege of combatancy. The existence of behind-the-scenes intelligence operations is a part of any military campaign. ${ }^{321}$ Intelligence gathering includes enemy military capabilities, surveillance of civilian personnel, and identification of strategic targets. ${ }^{322}$ In almost every state, intelligence units located either in the armed services or in a separate intelligence agency traditionally perform these activities. Regardless of their location within the government, however, these units rarely wear uniforms while engaged in covert or forward deployment on enemy territory. ${ }^{323}$ Such activities are ancillary to, but not a part of the deployment of any particular weapons system. Therefore, the existence of prior unprivileged intelligence operations, laying the preparatory work for later targeting, does not by itself make the intelligence operatives "co-deployers" of the

318. For a good description of drone deployments, see Michael N. Schmitt, Drone Attacks Under the Jus ad Bellum and Jus in Bello: Clearing the 'Fog of Law,' 13 Y.B. INT'L HUMANITARIAN L. 311, 313-14 (2010).

319. See Drake, supra note 317 , at 639 (discussing role of intelligence analysts in drone deployments).

320. Id. at $637-40$.

321. See, e.g., Len Scott, British Strategic Intelligence and the Cold War, in THE OXFORD HANDBOOK OF NATIONAL SECURITY INTELLIGENCE 138, 143 (Loch K. Johnson ed., 2010) (discussing British covert action and intelligence gathering after World War II).

322. For a general description of intelligence gathering, see Loch $\mathrm{K}$. Johnson, National Security Intelligence, in THE OXFORD HANDBOOK OF NATIONAL SECURITY INTELLIGENCE 3, 5-6 (Loch K. Johnson ed., 2010).

323. Id. at 13-14. 
weapons with the uniformed soldiers who later launch the ordinances. As long as the intelligence operatives are engaged in this type of ancillary work, the uniformed members who deploy the system retain their privilege of combatancy.

\section{CONCLUSION}

This Article elucidates a series of unorthodox positions regarding the combatant's privilege: that it applies in some non-international conflicts, that armed forces and not just militias are required to meet the four functional requirements for lawful belligerency, that non-state actors might qualify for the privilege if they fulfill the functional requirements, and that covert action is logically inconsistent with the privilege regardless of whether the deployment involves uniformed armed forces or covert operatives. Each of these conclusions departs significantly from repeated orthodoxy: the privilege is inapplicable in all non-international conflicts, regular armed forces are exempt from the functional requirements of belligerency, non-state actors can never be privileged, and uniformed soldiers are entitled to the privilege in covert actions.

Although the unorthodox positions defended in this Article depart significantly from the current literature and from received wisdom among state officials, near-universal agreement on a legal position is not, by itself, evidence of its correctness; each conclusion in this Article is justified once the basic structure of the laws of war is properly interrogated. History plays a large role in the argument: in particular the rich treatment of non-international conflicts by nineteenth-century scholars, as well as the complex state practice arising out of the U.S. Civil War. The Article also augments the standard fare of treaties and state practice with a heavy dose of conceptual argument. However, the disparate methodologies are not unconnected. The historical argument regarding the nineteenth century view is intended to clarify the preexisting legal framework preserved by Common Article 3 of the Geneva Conventions. The applicability of the functional criteria to regular armed forces is based, in part, on state practice and the lack of customary ascension to state forces that do not meet the criteria. Finally, the interpretation of the open arms and emblem requirements in the Third Geneva Convention depends on a conceptual analysis of their relationship to the principle of distinction and the nature of covert action-an under-theorized but increasingly urgent issue in asymmetric conflicts. 